CEO Personality: A Different Perspective on the Nonfamily Versus Family CEO Debate

Peer-reviewed author version

KELLECI, Ruveyda; LAMBRECHTS, Frank; VOORDECKERS, Wim \& HUYBRECHTS, Jolien (2019) CEO Personality: A Different Perspective on the Nonfamily Versus Family CEO Debate. In: Family Business Review, 32 (1), p. 31-57.

DOI: $10.1177 / 0894486518811222$

Handle: http://hdl.handle.net/1942/27460 


\title{
CEO personality: A different perspective on the nonfamily vs. family CEO debate
}

\author{
Ruveyda Kelleci \\ Hasselt University \\ Faculty of Business Economics | RCEF Research Center for Entrepreneurship and Family Firms \\ 1 Agoralaan \\ Diepenbeek, 3590, Belgium \\ Tel: 003211268606 \\ E-mail: ruveyda.kelleci@uhasselt.be \\ Frank Lambrechts \\ Hasselt University \\ Faculty of Business Economics | RCEF Research Center for Entrepreneurship and Family Firms \\ 1 Agoralaan \\ Diepenbeek, 3590, Belgium \\ Tel: 003211268693 \\ E-mail: frank.lambrechts@uhasselt.be \\ Corresponding author \\ Wim Voordeckers \\ Hasselt University \\ Faculty of Business Economics | RCEF Research Center for Entrepreneurship and Family Firms \\ 1 Agoralaan \\ Diepenbeek, 3590, Belgium \\ Tel: 003211268613 \\ E-mail: wim.voordeckers@uhasselt.be
}

Jolien Huybrechts

Maastricht University

School of Business and Economics | Department of Organization \& Strategy

53 Tongersestraat

6211 LM Maastricht, The Netherlands

Tel: 0031433883656

E-mail: j.huybrechts@maastrichtuniversity.nl

\begin{abstract}
Based on a unique, hand-collected dataset, we examine the personality traits of nonfamily and family CEOs in privately held Belgian family firms using the Occupational Personality Questionnaire. We find significant differences between nonfamily and family CEOs with regard to nine personality traits: independent minded, democratic, data rational, behavioral, detail conscious, conscientious, relaxed, worrying, and trusting. The findings suggest a very balanced personality profile for nonfamily CEOs and a rather strong-willed personality for family CEOs. Moreover, while the results suggest that the personalities of nonfamily CEOs matter for firm performance, no such indications were revealed for family CEOs.
\end{abstract}

Keywords: nonfamily CEO, family CEO, personality, Occupational Personality Questionnaire, upper echelons theory

\section{Acknowledgements}

We would like to thank Liesbeth Vandenrijt from Motmans \& Partners for providing access to unique CEO personality data and collaborating productively with us. We thank Koen Hendrix from VKW Limburg for his continuous support. We also would like to thank the anonymous reviewers for their many developmental comments and FBR Associate Editor Allison Pearson for her outstanding guidance in developing this article.

Citation: Kelleci, R., Lambrechts, F., Voordeckers, W., \& Huybrechts, J. (2018). CEO personality: A different perspective on the nonfamily versus family CEO debate. Family Business Review, https://doi.org/10.1177/0894486518811222 


\title{
CEO personality: A different perspective on the nonfamily vs. family CEO debate
}

\begin{abstract}
Based on a unique, hand-collected dataset, we examine the personality traits of nonfamily and family CEOs in privately held Belgian family firms using the Occupational Personality Questionnaire. We find significant differences between nonfamily and family CEOs with regard to nine personality traits: independent minded, democratic, data rational, behavioral, detail conscious, conscientious, relaxed, worrying, and trusting. The findings suggest a very balanced personality profile for nonfamily CEOs and a rather strong-willed personality for family CEOs. Moreover, while the results suggest that the personalities of nonfamily CEOs matter for firm performance, no such indications were revealed for family CEOs.
\end{abstract}

Keywords: nonfamily CEO, family CEO, personality, Occupational Personality Questionnaire, upper echelons theory 


\section{Introduction}

In today's highly competitive business environment, well-trained, experienced nonfamily CEOs are crucial for the growth and survival of many family firms (Blumentritt, Keyt, \& Astrachan, 2007; Chittoor \& Das, 2007). Indeed, several authors have reported that a large number of private family firms are led by nonfamily CEOs (Bennedsen, Nielsen, PérezGonzález, \& Wolfenzon, 2007; Block, 2011; Miller, Le Breton-Miller, Minichilli, Corbetta, \& Pittino, 2014). Privately held family firms often have difficulties obtaining motivated, competent executives, as they often seek such individuals among a small pool of relatives (Mehrotra, Morck, Shim, \& Wiwattanakantang, 2013). Nonfamily CEOs can help address these human resource limitations in private family firms (Blumentritt et al., 2007; Chittoor \& Das, 2007; Miller et al., 2014). Despite the critical relevance of nonfamily CEOs for family firm growth and survival, research on this topic remains surprisingly limited.

Prior studies have primarily focused on the performance effects of nonfamily CEOs versus family CEOs (Bennedsen et al., 2007; Pérez-González, 2006) as well as on some conditions that promote the success of each type of CEO (Blumentritt et al., 2007; Hall \& Nordqvist, 2008; Miller et al., 2014; Miller, Minichilli, \& Corbetta, 2013). However, current research has mainly focused on the characteristic of "family kinship" to explain the performance effects of nonfamily vs. family CEOs; such research has neglected other aspects of CEOs that may better explain their behavior. Indeed, prior research has found that the strategy and success of the family firm critically depends on the leadership behavior of the firm's CEO (Hambrick, 2007; Peterson, Smith, Martorana, \& Owens, 2003). Accordingly, if we want to extend our knowledge regarding the differences between nonfamily and family CEOs as well as the implications of those differences for firm performance or other firm outcomes, we should examine deeper constructs that explain CEO behavior. In this paper, we argue that CEO personality is one such construct that has been largely unexplored. Our first 
research question - "How are nonfamily CEOs and family CEOs different in terms of their personalities?" - addresses this research gap.

Personality reflects an individual's distinctive patterns of behavior, thought, and emotion that characterize his/her adaptation to life's situations (e.g., Funder, 2001; Mischel, 1993). Thus, these traits are indicative of an individual's tendencies or preferred ways of behaving, thinking and feeling (Allport, 1961; Saville, 2016), and they influence how individuals generally interpret and respond to situations, lending both consistency and individuality to a person's behavior (Feist, Feist, \& Roberts, 2017). Thus, insight into someone's personality (as a unique pattern of traits) allows predicting that individual's preferred behavior in a given situation (e.g., Jaccard, 1974; Sherman, Nave, \& Funder, 2010).

In this paper, we investigate $\mathrm{CEO}$ personality as captured by the "Occupational Personality Questionnaire (OPQ) model” (version 32i) (Bartram, Brown, Fleck, Inceoglu, \& Ward, 2006; Saville, Holdsworth, Nyfield, Cramp, \& Mabey, 1990). The OPQ is a robust, comprehensive way of understanding and predicting an individual's preferred job-relevant behavior. The OPQ personality measure is widely used and highly researched; it has good reliability and validity credentials (e.g., Robertson \& Kinder, 1993; The British Psychological Society, 2007) and predicts several work-related outcomes in a reliable and valid way (e.g., Bartram, 2005; Fisher, Hunter, \& Macrosson, 2001; Saville et al., 1990; Vinson, Connelly, \& Ones, 2007). The OPQ measures 32 personality traits (416 items) of particular relevance to an occupational setting. These traits are grouped into three broad domains, which we will use as an organizing structure for building our hypotheses in the "literature review and hypotheses development" section. Relationships with People indicates how an individual relates to others (e.g., independent minded, controlling). Thinking Styles refers to how an individual typically thinks (e.g., detail conscious, data rational). Feelings and Emotions represents how an individual emotionally relates to a situation (e.g., worrying, trusting). 
With our second research question, we address another critical omission in the family business literature. Drawing on upper echelons theory, we investigate "How do the personality traits of nonfamily CEOs and family CEOs relate to family firm financial performance?" Because of their unique role as chief cognizer and attention regulator (Herrmann \& Nadkarni, 2014), CEOs' powerful impact on firm strategy and financial performance is well established in upper echelons theory (Finkelstein, Hambrick, \& Cannella, 2009). Within this logic, the study of CEO personality has emerged as an important topic in strategic management, and a growing body of work has highlighted that the CEO's personality is reflected in the strategic decisions, structure, and performance of the organization he/she leads (Hambrick, 2007; Schein, 2010). Indeed, as Hambrick, Finkelstein, and Mooney (2005) state, "we can imagine no more fertile terrain in the organization sciences today than the study of executive personality ...” (p. 503).

We base our study on a unique, hand-collected dataset of 25 nonfamily CEOs and 19 family CEOs in Belgian private family firms. This dataset provides exceptionally rich data on these CEOs' personality traits. Using a sample of this size is common practice and is consistent with other published studies on CEO personality (see also: Berson, Oreg, \& Dvir, 2008; O’Reilly, Caldwell, Chatman, \& Doerr, 2014; Peterson et al., 2003). Moreover, access to this type of detailed, high-quality data on $\mathrm{CEO}$ personality is rather exceptional, as obtaining CEO personality data is notoriously difficult (e.g., Hambrick, 2007; O'Reilly et al., 2014).

The results of our study offer important new insights into the unique personalities of both nonfamily and family CEOs in private family firms. We also examine differences in the personalities of both types of CEOs and the implications of those differences for firm performance. The results contribute to the literature on family business and strategic leadership in various ways. First, our study addresses a limitation in the current performance 
debate concerning nonfamily vs. family CEOs by looking at psychological attributes, namely personality traits, that drive CEO behavior and better explain differences between both types of CEOs. Second, our study follows recent calls for more research regarding the characteristics of nonfamily CEOs in family firms (Binacci, Peruffo, Oriani, \& Minichilli, 2016; Blumentritt et al., 2007; Hall \& Nordqvist, 2008). Our study thoroughly articulates the (differences in) personalities of nonfamily and family CEOs and adds surprising new insights into this research field. In this way, we offer deeper explanations of previous findings in the family business literature related to nonfamily CEOs and call into question some deeply held assumptions about how family CEOs and nonfamily CEOs differ. Third, we extend upper echelons theory into a context with a "peculiar" ownership structure (Simsek, Jansen, Minichilli, \& Escriba-Esteve, 2015) by examining CEO personality in closely held private family firms. Finally, we formulate general implications for upper echelons theory.

\section{Literature review and hypotheses development}

\section{Personality differences between nonfamily and family CEOs}

As indicated in the introduction, personality is reflective of a person's tendencies or preferred ways of behaving, thinking and feeling, and a better understanding of CEO personality allows us to make predictions about a CEO's preferred behavior in a given situation. To our knowledge, there is no research dedicated to theorizing and empirically testing the differences in personality between nonfamily and family CEOs. There are, however, a few studies that link some personality traits of family CEOs to firm outcomes such as entrepreneurial orientation and succession (Marler, Botero, \& De Massis, 2017; Pittino, Visintin, \& Lauto, 2017). Moreover, there are also a few papers that are specifically devoted to various personality traits of owner-managers (e.g., Kets de Vries, 1985; Miller, 2015), one explicitly comparing these traits with the personality of nonfamily managers (Schein, 1995). Because family CEOs are, in general, owner-managers, we also use these studies to develop 
the theoretical rationale for our hypotheses. Table 1 presents an overview of the abovementioned studies.

\section{***Insert Table 1 about here***}

From Table 1, we learn that there is little prior theoretical or empirical work dedicated to the personality of family CEOs, and even less to the personality of nonfamily CEOs. As a result, family business researchers are largely left only with assumptions about the personalities of these two groups and how they differ.

Because of the novelty of our topic, the paucity of prior knowledge to work from, and the exploratory nature of our research questions, we measure all 32 personality traits grouped into OPQ's three broad categories (relationships with people, thinking styles, feelings and emotions) (see also "Measures"). This approach enables us to provide and explore comprehensive personality profiles of family and nonfamily CEOs. We only build hypotheses around those traits per category that resonate most strongly with the current family business literature, that is, where the literature motivates us to expect differences in traits between family and nonfamily CEOs. This approach enables both an exploration of prescribed relationships and the ex post discovery of interesting findings. In what follows, we first build hypotheses concerning personality differences between family and nonfamily CEOs using the three broad OPQ categories as an organizing framework, and, second, drawing on upper echelons theory (Hambrick, 2007; Finkelstein et al., 2009), we build a hypothesis concerning the differential effect of nonfamily and family CEOs' personalities on firm performance.

\section{Nonfamily vs. family CEOs: Relationships with people}

The first domain, Relationships with People, reflects how an individual relates to others (Bartram et al., 2006; Saville et al, 1990). In this area, three traits seem to resonate most strongly with the literature: "independent minded" (i.e., the degree to which a person tends to follow his/her own approach, independent of the group consensus); "controlling" 
(i.e., the degree to which a person likes to be in charge, tells others what to do, and takes control); and "democratic" (i.e., the degree to which a person consults widely and involves others in decision making) (Bartram et al., 2006).

Previous research has suggested that family CEOs have a strong preference for control (Kets de Vries, 1985). Indeed, family CEOs like "being in charge and manage their lifework, the family firm" (Barth, Gulbrandsen, \& Schønea, 2005, p. 125). They are thus expected to concentrate decision-making authority in their own hands. Nonfamily CEOs, on the other hand, implement a more participatory leadership style (Mullins \& Schoar, 2016; see also Schein, 1995). Thus, we deduce that, compared to family CEOs, the personality of nonfamily CEOs is likely characterized as more democratic. This prediction is consistent with the observation of Blumentritt et al. (2007) and Hall and Nordqvist (2008) that successful nonfamily CEOs tend to have a deep "understanding of the family's goals and meanings of being in business" (Hall \& Nordqvist, 2008, p. 58), which helps them to balance business with family objectives and to align with the owning family.

It has also been suggested that family CEOs are strong-minded and have strong opinions about how things should be done (Dyer, 1989; Schein, 1995). This suggestion is consistent with research by Kets de Vries (1985) and Miller (2015) indicating that family CEOs do not like to take orders from other people and instead prefer a high level of independence. Although nonfamily CEOs also favor a considerable amount of autonomy in performing their role (Chang \& Shim, 2015), not being part of the family implies that they must cope with and accept the opinions of the owning family, even when those opinions are inconsistent with their own views (Blumentritt et al., 2007). Given the discussion thus far, we propose the following:

Hypothesis 1: Compared to family CEOs, the personality of nonfamily CEOs is characterized as less controlling, more democratic, and less independent minded. 


\section{Nonfamily vs. family CEOs: Thinking styles}

The second area, Thinking Styles, represents how an individual typically thinks (Bartram et al., 2006; Saville et al, 1990). In this domain, the literature seems to echo four traits in particular: "detail conscious" (i.e., the degree to which a person focuses on detail and likes to be methodical, organized and systematic); "data rational" (i.e., the degree to which a person likes working with numbers, enjoys analyzing statistical information, and bases decisions on facts and figures); "forward thinking" (i.e., the degree to which a person takes a long-term view, sets goals for the future and is more likely to take a strategic perspective); and "behavioral" (i.e., the degree to which a person attempts to understand motives and behaviors, and enjoys analyzing people) (Bartram et al., 2006).

Several prior studies allow us to predict that the personality of nonfamily CEOs is likely characterized as more detail conscious and data rational. Schein (1995) suggests that nonfamily CEOs are specific in their analytical orientation, primarily focused on details and their consequences, whereas family CEOs are more intuitive and holistic in their thinking, focused on the total picture and broader patterns.

Nonfamily CEOs are also believed to have a more rational management style (Carrasco-Hernandez \& Sánchez-Marin, 2007; Dyer, 1989; Schein, 1995), approaching the family business in a more objective way (Block, 2011). By contrast, it is generally assumed that the behavior of family CEOs is driven by socioemotional wealth considerations: "the non-financial aspects of the firm that meet the family's affective needs such as identity, the ability to exercise family influence and the perpetuation of the family dynasty" (GómezMejía, Haynes, Núñez-Nickel, Jacobson, \& Moyano-Fuentes, 2007, p. 106). Nonfamily CEOs, given their lack of family ties, are assumed to have less emotional basis for their behavior (Chua, Chrisman, \& Sharma, 2003) and to act primarily from an economic, financial logic (Miller et al., 2014). 
From previous research, we derive that family CEOs tend to be more forward thinking than nonfamily CEOs. Indeed, family CEOs are known for their long-term orientation and long tenures, as they build their own identities through their family firms (Schein, 1995) and tend to hold office until the next generation is ready to take over (Le Breton-Miller \& Miller, 2006). These long tenures and consideration for the next generation are said to increase the investment horizon of family CEOs, enabling them to commit to projects that require several years before becoming beneficial to firm performance (James, 1999; Le Breton-Miller \& Miller, 2006). Nonfamily CEOs, on the other hand, have much shorter tenures (Huybrechts, Voordeckers, \& Lybaert, 2013) and are assumed to take a short-term point of view (Schein, 1995) with a focus on short-run performance.

We expect that nonfamily CEOs also tend to think more behaviorally, trying to understand and analyze the motives and behavior of the family. This style of thinking seems suitable given that nonfamily CEOs are likely confronted with great uncertainty about the outcomes of their actions, uncertainty that stems from having incomplete information about the family's family-centered, noneconomic goals (Chrisman, Memili, \& Misra, 2014). Given the above discussion, we propose the following:

Hypothesis 2: Compared to family CEOs, the personality of nonfamily CEOs is characterized as more detail conscious, more data rational, less forward thinking, and more behavioral.

\section{Nonfamily vs. family CEOs: Feelings and emotions}

The third domain, Feelings and Emotions, reflects how an individual emotionally relates to a situation (Bartram et al., 2006; Saville et al, 1990). In this category, three traits seem to resonate most strongly with the literature: "worrying" (i.e., the degree to which a person feels nervous before important occasions and worries about things going wrong); "relaxed" (i.e., the degree to which a person finds it easy to relax and is generally calm); and 
"trusting" (i.e., the degree to which a person trusts people, sees others as reliable and honest, and believes what others say) (Bartram et al., 2006).

Based on previous research, we predict that the personality of family CEOs is likely characterized as less relaxed and more worried than the personality of nonfamily CEOs. Being a family CEO is an emotional endeavor, not in the least because of the great personal consequences that are linked with the fate of the family firm. Indeed, family CEOs are financially, psychologically (self-identity) and socio-emotionally deeply invested in their firms (Cannella \& Shen, 2001). Many family CEOs are said to experience a great amount of tension; they may feel that they are living on the edge and worry that their success will not last (Kets De Vries, 1985). Nonfamily CEOs, on the other hand, tend to take more risks (Huybrechts et al., 2013; Miller et al., 2014), which suggests that they are less worried about things going wrong. Schein (1995) also suggests that family CEOs, more than nonfamily CEOs, are exposed to anxiety and stress inherent in building their organizations.

Moreover, we derive from previous research that family CEOs are likely less trusting in comparison with nonfamily CEOs. That is, strongly linked to their inclination for control, family CEOs are suggested to be more suspicious of others and to have a (strong) distrust for the world around them (Kets De Vries, 1985). This also makes them less likely to take suggestions from others, as they are said to be warier of other people's intentions (Miller, 2015). Nonfamily CEOs, in general, also delegate more tasks and apply a more participatory leadership style (Mullins \& Schoar, 2016), which suggests they are more trusting of other people. Given this discussion, we hypothesize as follows:

Hypothesis 3: Compared to family CEOs, the personality of nonfamily CEOs is characterized as more relaxed, less worrying, and more trusting.

\section{The effect of the personalities of family and nonfamily CEOs on firm performance}


The upper echelons perspective has established that CEO personality matters for organizations (Hambrick, 2007; Hambrick \& Mason, 1984). Indeed, "the central premise of upper echelons theory is that executives' experiences, values and personalities greatly influence their interpretations of the situations they face and, in turn, affect their choices" (Hambrick, 2007, p. 334). As understanding someone's personality enables prediction of what that person will do in a given situation, by studying executive personality, one can predict which behaviors someone will prefer in the workplace and consequently anticipate that person's influence on several organizational dimensions, such as strategy, innovation, and ultimately firm performance. Indeed, there is ample evidence that executive personality predicts leadership behavior (e.g., Bono \& Judge, 2004; Judge, Bono, Ilies, \& Gerhardt, 2002), which in turn influences firm performance (e.g., Colbert, Barrick, \& Bradley, 2014; Herrmann \& Nadkarni, 2014; Nadkarni \& Herrmann, 2010). Nadkarni and Herrmann (2010), for example, find evidence for the positive influence of CEO emotional stability, agreeableness (until an optimal point is reached), extraversion and openness to experience on firm financial performance. In that study, the personality trait of conscientiousness had a negative impact. In another study by Colbert et al. (2014), conscientiousness was positively linked with firm financial performance, as was the case for CEO emotional stability and openness.

Similarly, we can expect that the personality traits of family and nonfamily CEOs affect performance but that the effects of individual traits could differ between the two groups. For instance, based on the family business literature, we can expect that nonfamily CEOs with a preference for taking control could have an unfavorable effect on firm performance. Indeed, having to take into account the priorities and goals of the owning family, nonfamily CEOs who prefer to take control might struggle, as frictions between the CEO and the owning family could be demotivating, negatively impacting firm performance 
(Miller et al., 2014). On the other hand, taking family objectives into consideration when making decisions, and thus being more democratic, is regarded as beneficial to firm success (Blumentritt et al., 2007). For family CEOs, these personality traits could have a different outcome than for nonfamily CEOs. Family CEOs, having a strong personal authority - and taking control - allows them to operate under fewer internal constraints, thus empowering them to make fast decisions at their own discretion (Gedajlovic \& Carney, 2010). This concentrated decision-making rather than being democratic may be beneficial to firm performance, as it increases speed to market and strategic flexibility (Gedajlovic, Lubatkin, \& Schulze, 2004).

As the examples of "controlling" and "democratic" demonstrate, certain personality traits may affect firm performance differently when possessed by family compared to nonfamily CEOs. As a result, we propose the following hypothesis:

Hypothesis 4: Family and nonfamily CEOs' personalities are differently associated with firm financial performance.

\section{Methodology}

\section{Sample}

To obtain access to CEO personality data, we set up a collaboration with Motmans \& Partners, a Belgian human resources consultancy firm licensed to administer the OPQ. We chose this collaboration for two reasons. First, previous studies on CEO personality show that obtaining deep CEO personality data is a very challenging task, as CEOs often refuse to participate (e.g., Berson et al., 2008; Peterson et al., 2003). Second, our collaboration partner possessed detailed OPQ reports - which were administered by trained and experienced professionals - on the personalities of family and nonfamily CEOs in Belgian private family firms. 
The data that were made available consisted of the respondents' scores on the subscales of the OPQ32i (e.g., Bartram et al., 2006). Additional data concerning the demographics of the respondents were collected through LinkedIn, press releases, company websites, and personal e-mail contact. The data consist of a representative sample of 25 nonfamily CEOs and 19 family CEOs of privately held Belgian family firms. Our sample size is in line with those used in other influential personality studies (e.g., Berson et al., 2008, n = 26; Peterson et al., 2003, $\mathrm{n}=17$; O'Reilly et al., 2014, $\mathrm{n}=32$ ). Moreover, the distribution of sample characteristics with regard to respondents' age, gender and education proved to be comparable to that of other academic studies on Belgian CEOs (e.g., Buyl, Boone, \& Hendriks, 2014; Buyl, Boone, Hendriks, \& Matthyssens, 2011) ${ }^{1}$. Descriptive statistics can be found in Table 2.

\section{***Insert Table 2 about here***}

While our paper is focused on CEO personality, we also wanted to provide some further information about the work environment of the CEOs in our sample. We identified the family firms in which the CEOs worked through the websites LinkedIn and Trends Top, an online database that provides financial and nonfinancial information on Belgian firms. Family firms were identified as such when at least $50 \%$ of the shares were family-owned and the CEO perceived the firm to be a family firm (Chrisman, Chua, \& Sharma, 2005; Westhead \& Howorth, 2006). We used Trends Top and the financial database Belfirst, supplied by Bureau Van Dijk, to collect additional information on family ownership and family involvement of the family firms for which the CEOs in our sample worked. We learned that the family firms in our sample were characterized by a high level of family ownership and family involvement. More specifically, the firms led by a family CEO and those led by a nonfamily CEO had an average of $99.81 \%$ and $96.08 \%$ family ownership, respectively. In family CEO-

\footnotetext{
${ }^{1}$ For example, the mean CEO age in Buyl et al. (2014) was 45.75; in Buyl et al. (2011), it was 45.55. These are comparable to a mean of 42.45 in our study. The mean CEO education level in Buyl et al. (2011) was 88\% holding a higher education degree compared to a mean of $87 \%$ in our study.
} 
led firms, the management team comprised $43.58 \%$ family members on average. For nonfamily CEO-led firms, this percentage was 56.64\%. With regard to family member representation on the board of directors, family CEO-led and nonfamily CEO-led firms, respectively, had $72.28 \%$ and $53.59 \%$ family board members on average. Firms led by a family CEO were 27 years old and employed 52 people on average. The nonfamily CEO-led firms in our sample were bigger and slightly older; on average, they employed 179 people and were 30 years old.

\section{Measures}

Personality was assessed using the ipsative version of the OPQ32i, Belgian Dutch version (Bartram et al., 2006). The items per scale are displayed as a "forced-choice" format, which requires the respondents to select one least preferred and one most preferred item from a set of four alternatives. The OPQ is designed to measure personality traits of particular relevance to an occupational setting and to predict work-related outcomes (Vinson et al., 2007). The OPQ is frequently used in academic studies that have examined various workrelated phenomena, such as job competencies (Bartram, 2005; Robertson \& Kinder, 1993; Saville, Sik, Nyfield, Hackston, \& Maclver, 1996), personality measurements (Barrett, Kline, Paltiel, \& Eysenck, 1996; Beaujouan, 2000; Lievens, Harris, Van Keer, \& Bisqueret, 2003; Perry, Hunter, Witt, \& Harris, 2010), and team functioning (Fisher et al., 2001).

The OPQ has been shown to serve as a valid and reliable personality measurement instrument across organizations, nations, and time periods (Bartram, 2005, 2012, 2013; Bartram \& Brown, 2004; Robertson \& Kinder, 1993; Saville et al., 1996; Saville \& Willson, 1991; The British Psychological Society, 2007). Because the OPQ is the property of Saville and Holdsworth Ltd (SHL), a global developer of psychometric assessment tests, we received only the candidates' scores on the subscales (for a similar approach, also see: Lievens et al., 2003; Perry et al., 2010). Therefore, we were unable to compute the reliability of the scales. 
Several studies have found satisfactory reliabilities (e.g., Bartram, 2007; Bartram \& Brown, 2005; Matthews, Stanton, Graham, \& Brimelow, 1990). For the OPQ32i Belgian Dutch version, SHL (2011) reported a mean internal consistency of 0.78 with the alpha coefficients for the various subscales ranging from 0.70 to 0.89 . Test-retest reliabilities varied between 0.64 and $0.91($ mean $=0.79)$. Finally, personality instruments that adopt a clear work-related frame of reference, such as the OPQ, have been shown to yield higher validities than instruments that are more general (Hunthausen, Truxillo, Bauer, \& Hammer, 2003; Ones \& Viswesvaran, 2001). It should be noted that the OPQ was developed as a work-related measure of personality, and the item content and scales were developed by working with people in industry. The OPQ inventories cover a wider range of personal attributes than do instruments developed from a personality theory focus, such as the five-factor model, because the development process was centered on covering all aspects of personality that are considered to be of relevance in the workplace (Bartram, 2005, p. 1186). This greater breadth is of great importance for this study, as our aim is to holistically investigate the personality profile of nonfamily and family CEOs.

The OPQ32i is offered in 28 languages (SHL, 2011) and consists of 416 items measuring 32 subscales (personality traits) (Bartram \& Brown, 2004). For this study, all of the versions of the questionnaire were "Belgian Dutch", as this version is always used for people within the Dutch-speaking region of Belgium. Several studies have demonstrated construct invariance for the OPQ32i scales across a wide range of countries and different language versions (Bartram, 2012, 2013). The 32 personality traits are grouped into three broad domains: interpersonal relationships, thought styles, and feelings and emotions.

Due to copyright restrictions, we are not allowed to discuss the items per scale. However, in the Appendix, we provide a Table with a definition for each of the 32 subscales. 
These definitions describe the behaviors that are associated with a low score, a high score, and an average score on each subscale. For example, a low score on the subscale "persuasive" means that an individual rarely pressures others to change their views, dislikes selling and is less comfortable during negotiations. By contrast, individuals with a high score on this subscale enjoy selling, are comfortable during negotiations and like to change other people's views. An average score means that depending on the situation at hand, the individual prefers to adjust his or her behavior. As with many other personality questionnaires, OPQ32i scores are reported using a standard ten "sten" scale, which provides a scale of ten evenly spaced units. A sten score is calculated as follows:

$$
\begin{gathered}
Z=\frac{\text { raw score }- \text { mean population score }}{\text { standard deviation }} \\
\text { Sten }=Z \times 2+5.5
\end{gathered}
$$

Stens are based on the principles of standard scores and indicate an individual's position with respect to the population of values, that is, the values of the "norm group". Norms are part of the measurement procedure and provide the scaling that is necessary to assign a value and meaning to an individual's raw scores obtained from the OPQ32i. The main purpose of norm groups is to provide a means of converting raw scores into standard scores such that the scores of individuals become interpretable. Norms make it possible to determine whether an individual's scores are average, higher than or lower than the mean distribution of values of the general population on a standardized scale. As our sample consists of Belgian CEOs, the norm group in our study consists of the general Belgian population. Individual sten scores are defined by reference to a standard normal distribution. The sten scores range from 1 to 10 and have a mean of 5.5 and a standard deviation of 2 . Therefore, individual sten scores represent half of one standard deviation. Given a mean of 5.5 and a standard deviation of 2 , the scores of an individual are interpreted as low in the case 
of a sten between 1 and 3.5, as average in the case of a sten score between 3.6 and 7.5, and as high in the case of a sten score higher than 7.5 (Bartram et al., 2006).

For the second research question, the performance data of the firms were collected using the financial database Belfirst, supplied by Bureau Van Dijk. Because of the weaknesses inherent in any one measure of performance (Barnett \& Salomon, 2012; Venkatraman \& Ramanujam, 1986), two indicators of performance were used: return on assets (ROA) and return on equity (ROE). These two accounting measures are widely used in studies on the impact of top executives' characteristics on firm performance (e.g., Cannella \& Shen, 2001; Henderson, Miller, \& Hambrick, 2006; Miller et al., 2014) and in CEO succession research (e.g., Bennedsen et al., 2007; Cucculelli \& Micucci, 2008; PérezGonzález, 2006). Following empirical studies on CEO succession (e.g., Bennedsen et al., 2007; Karaevli, 2007; Pérez-González, 2006), we adjust for industry effects by subtracting from firm ROA and ROE the annual average ROA and ROE, respectively, of the 2-digit industry in which the firm operates. We have used three different operationalizations of both performance measures: the industry-adjusted ROA and ROE one year after the CEO was hired and the average industry-adjusted ROA and ROE for the two- and three-year periods following the appointment of the CEO. Although prior research suggests that a one-year lag is reasonable enough to reflect the performance impact of a CEO (Ling, Simsek, Lubatkin, \& Veiga, 2008), we nevertheless also averaged performance across multiple years, as this reduces the bias resulting from single-time-point outliers (Cannella, Park, \& Lee, 2008; Carpenter \& Sanders, 2002) and allows the performance impact of a newly hired CEO to be more fully captured (Shen \& Cannella, 2002).

\section{Procedure}

As the OPQ32 is designed and validated for supervised administration, all questionnaires were administered by appropriately trained and licensed psychometricians 
from the HR consultancy firm with whom we collaborated. The OPQs were administered between 2008 and 2015. The variation in the timing of the data collection is not an issue, as personality traits have been shown to be very stable over time (Terracciano, McCrae, \& Costa, 2010). The time to complete the questionnaire varied from 45 minutes to one hour. We interpreted our results in close cooperation with a certified OPQ analyst from our collaboration partner. This additional cross-check ensured the reliability and accuracy of our interpretations and findings.

\section{Analysis and discussion of the results}

\section{Personality traits of nonfamily CEOs vs. family CEOs}

Matching the research method to the research question is of critical importance to any study. The first aim of our study is to gain a detailed understanding of nonfamily and family CEO personalities and their potential differences. Table 3 presents the results of these analyses.

\section{***Insert Table 3 about here***}

Given the nature of our first research question, we first computed the mean scores of both types of respondents on the OPQ subscales. Second, to investigate the differences in personality between the two groups, we performed an independent samples t-test. We also calculated the Cohen's d, which is a measure of the effect size. The Cohen's d measures the magnitude of the significant differences between nonfamily and family CEOs and indicates the practical significance of the results (Cohen, 2013). A positive value indicates a positive effect size, while a negative value indicates a negative effect size. Cohen (2013) suggested that absolute values of $d$ lower than 0.2 indicated a small effect size, values between 0.2 and 0.5 indicated a medium effect size, and values over 0.5 indicated a large effect size.

To cross-check our findings, we also performed the non-parametric Mann-Whitney U test. The results of this additional test remain similar to our primary findings. Unlike the t-test, 
the Mann-Whitney U test revealed an additional significant difference between nonfamily and family CEOs at the $10 \%$ level on the subscale "socially confident" (p-value $=0.061)$.

\section{Average profile of nonfamily and family CEOs and their significant differences}

Based on their scores, nonfamily and family CEOs demonstrate a preference for certain behaviors, which we will discuss below. Every score (low, average, high) is reported and assessed in comparison to the norm group and interpreted according to the definitions of the OPQ. In addition to discussing the general profile of nonfamily and family CEOs, we also highlight the significant differences in scores between the two groups. We discuss the results per dimension of the OPQ, namely interpersonal relationships, thought styles, and feelings and emotions. Figures $1 \mathrm{a}, 1 \mathrm{~b}$ and $1 \mathrm{c}$ visually depict the personality profiles of the nonfamily and family CEOs per dimension of the OPQ.

***Insert Figures 1a, 1b, 1c about here***

Relationships with people. Based on their high scores on "persuasive", both nonfamily and family CEOs clearly demonstrate a commercial tendency, which means they are individuals who like to sell, who feel very comfortable during negotiations and who enjoy changing other people's views. Both types of CEOs are individuals who like to be in charge and take responsibility, as indicated by their high scores on "controlling". They like to have final responsibility and prefer to organize the work of others. Nonfamily and family CEOs both have average scores on "outspoken", which means that depending on the situation at hand, they prefer to clearly express disagreement, defend their own opinion and criticize others, or refrain from criticizing others and keep their opinion to themselves. While nonfamily CEOs have an average score on "independent minded", family CEOs show a significantly higher score on this subscale $(\mathrm{p}<0.001)$. Thus, whereas nonfamily CEOs are depending on the situation - equally likely to accept majority decisions and follow consensus or disregard majority decisions and follow their own approach, family CEOs are not. Instead, 
the latter prefer to follow their own approach and do not like being told what to do; they are not sensitive to authority figures and will only follow majority decisions or procedures when they are personally truly convinced that doing so is the best decision or procedure. The positive side of such a high score on this subscale is that family CEOs are individuals who have clear ideas and personal vision. However, a potential downside may be that these CEOs are unable to work well with people who are also very independent minded.

Nonfamily and family CEOs have the same average score on "outgoing", which means that sometimes they are talkative and lively in groups, while at other times they prefer to be more quiet and reserved. Nonfamily and family CEOs enjoy other people's company, but at the same time, they feel comfortable spending time away from other people, as indicated by their average scores on "affiliative". Both family and nonfamily CEOs have average scores on "socially confident", indicating that they experience little or no discomfort when meeting new people or during formal situations.

Both types of CEOs have an average score on the subscale "modest"; thus, depending on the situation, they will emphasize their personal strengths, achievements and successes or remain quiet about them. The nonfamily and family CEO differ significantly in their scores on "democratic" ( $p<0.05)$. Nonfamily CEOs are more democratic; depending on the situation, they will or will not prefer to involve others in their decision making. Family CEOs, by contrast, have a lower average score on this subscale, meaning that they prefer to make decisions without consulting others. Lastly, as indicated by their average scores on "caring", nonfamily and family CEOs can focus their attention both on task-related issues and on personal or relational issues while working. Depending on the situation at hand, they prefer to be considerate, helpful and supportive towards their colleagues or to remain detached from the personal problems of others. These findings regarding relationships with people are generally in line with hypothesis 1 . That is, although both family and nonfamily CEOs tend to 
score high on controlling, nonfamily CEOs are significantly more democratic and less independent minded than family CEOs.

Thought styles. Nonfamily CEOs and family CEOs significantly differ in their score on the subscale "data rational" ( $\mathrm{p}<0.01)$. Nonfamily CEOs prefer to work with numbers, analyze statistical information, and base their decisions on facts and figures, which is in line with hypothesis 2 . Family CEOs are not analysts; they are more likely to follow their gut feelings, and they base their decisions on statistics to a lesser extent than do nonfamily CEOs. This finding indicates that family CEOs are "doers" - meaning they prefer to take action instead of carefully analyzing - while nonfamily CEOs are thinkers. Both nonfamily and family CEOs have an average score on "evaluative"; depending on the situation, they may or may not critically evaluate information, focus on potential limitations and look for errors. In accordance with hypothesis 2, nonfamily CEOs have significantly more emotional intelligence than do family CEOs $(\mathrm{p}<0.05)$, as shown by their scores on "behavioral". Nonfamily CEOs enjoy analyzing people, and they try to understand others' motives and behavior. We see that this score balances with their score on "data rational". Thus, nonfamily CEOs are able to balance emotions/feelings and logic. By contrast, family CEOs have lower emotional intelligence; they prefer not to analyze or understand people's motives and behaviors.

Both nonfamily and family CEOs have an average score on "conventional", indicating they can balance the new with the old. Both types of CEOs have respect for existing methods and traditions but also have a very positive attitude concerning change and new or less conventional approaches or methods. Nonfamily and family CEOs are equally interested in discussing practical and theoretical issues/abstract concepts, as indicated by their average scores on "conceptual". Both types of CEOs score slightly above average on "innovative", meaning they enjoy generating new ideas, being creative and thinking of original solutions. 
Both nonfamily and family CEOs have average scores on "variety seeking" and "adaptable"; depending on the situation, they prefer to stick to their routine or to seek out variety and change their routines.

Nonfamily CEOs have a remarkably high score on "forward thinking", revealing that they are more likely to take a strategic perspective and set goals for the future. Combined with their lower average score on "detail conscious" and "conscientious", this means nonfamily CEOs are mainly focused on the bigger strategic picture; they have enough flexibility and are not preoccupied with details or restricted by deadlines. Contrary to what we proposed in hypothesis 2, family CEOs do not score significantly higher on "forward thinking" compared to nonfamily CEOs. In line with hypothesis 2, which proposes that the personality of nonfamily CEOs can be characterized as more analytical compared to family CEOs, family CEOs have a significantly lower score on "detail conscious" $(\mathrm{p}<0.1)$ and "conscientious" ( $\mathrm{p}$ $<0.05)$ compared to nonfamily CEOs. This finding means that family CEOs are absolutely not preoccupied with detail and are less organized and systematic. Family CEOs do not seem to follow a logic while working or acting, which probably makes them difficult for other people to follow. Instead, family CEOs prefer to do what they think is most interesting or relevant at the time. A potential downside of such a low score is that family CEOs may not finish what they start, as they can jump from one task to another. However, an advantage is that family CEOs are very flexible individuals and can maintain their fast pace of work, as they do not lose time getting lost in the details or making numerous calculations or analyses before acting and making decisions. Lastly, nonfamily and family CEOs have low scores on "rule following". This suggests that neither type of CEO will be restricted by regulations or procedures; they will follow the rules as long as they find the rules to be useful; however, if they do not agree with or see the utility of those rules, they have a tendency to break them. 
Feelings and emotions. In line with hypothesis 3, nonfamily CEOs are resilient, as shown by their scores on "relaxed" and "worrying". Nonfamily CEOs find it easy to relax, and they can keep their calm before important occasions. By contrast, family CEOs find it very difficult to relax; they are anxious and feel tense. Combined with their relatively high score on worrying, family CEOs seem to be naturally nervous individuals. The difference in scores between the two types of CEOs on the subscales "relaxed" $(p<0.01)$ and "worrying" $(\mathrm{p}<0.1)$ is statistically significant. This result could point to a difference between nonfamily and family CEOs in general temperament; family CEOs may naturally be more nervous or anxious. Nonfamily and family CEOs have average scores on "tough minded", which indicates that they are not easily offended and can appropriately cope with personal comments or criticism.

While family CEOs score a little lower on "optimistic" than do nonfamily CEOs, both groups' scores remain average; depending on the situation, both groups of CEOs will or will not be concerned about the future and will focus on the negative or positive aspects of a situation. In accordance with hypothesis 3, nonfamily CEOs are significantly more "trusting" than family CEOs $(\mathrm{p}<0.01)$, meaning nonfamily CEOs have a trusting view of "man"; they see others as reliable and honest. However, family CEOs are less trusting of the intentions of others. Both types of CEOs are "emotionally controlled"; depending on the situation, they will either openly express their feelings and emotions or conceal them.

Nonfamily and family CEOs have average scores on "vigorous", meaning they thrive on activity and like to keep busy, while they also enjoy working at a steady pace. Lastly, nonfamily and family CEOs are both very dynamic, as shown by their higher average scores on "competitive", "achieving" and "decisive". While nonfamily CEOs enjoy competitive activities and feel the need to win, they sometimes feel like taking part is more important than winning. By contrast, family CEOs feel a special need to do better than the rest, to defeat 
others, as evidenced by their higher score on "competitive". Both types of CEOs like to use demanding goals and targets to stay motivated. Finally, both groups are fast decision makers and prefer to reach conclusions quickly.

Summary of the general profile of the nonfamily and family CEO. When the results over the three dimensions are taken together, it becomes clear that nonfamily CEOs have a very balanced personality profile that lacks any extreme low or high scores, which allows those CEOs to be very flexible in their behavior. Nonfamily CEOs' scores indicate they are able to find a balance between competing issues, such as emotions and business; they can be team players while also working on their own; they are independent minded yet consider the input of others when the situation calls for it. Accordingly, nonfamily CEOs can be considered "shape shifters", individuals who are able to behave appropriately and in accordance with a specific situation or person. However, family CEOs demonstrate some unbalanced traits in their personalities, as shown by their extreme high or low scores. Family CEOs are less trusting of people; combined with their being very independent minded and competitive, this could indicate that they are less likely to be team players. They do not like to follow the rules of others and are significantly less democratic, suggesting they can be quite dominant in their working relationships with others. Whereas nonfamily CEOs are "shape shifters", family CEOs may have difficulty adapting to different situations or persons due to their strong-willed personalities.

\section{The personality traits of nonfamily CEOs and family CEOs in relation to family firm}

\section{performance}

To examine our second research question, we conducted a canonical correlation analysis (CCA) on the samples of both nonfamily CEOs and family CEOs. This was especially appropriate for the purpose of our study, as a CCA assesses the correlation between the two composite variables called canonical variates, one representing a set of independent 
variables (i.e., personality), "the predictor set", and the other representing a set of outcome variables (i.e., firm financial performance), "the criterion set" (Hair, Anderson, Tatham, \& Black, 1998; Sherry \& Henson, 2005). Following the structure of the OPQ, we have divided the 32 personality subscales into seven "predictor sets" and related these "predictor sets" to different "criterion sets", consisting of different combinations of the firm performance variables (industry-adjusted ROA and ROE one year after recruitment of the CEO as well as the two- and three-year average industry-adjusted ROA and ROE). Due to space limitations, we only report the significant CCA models. It is important to note that we only obtained significant results for the group of nonfamily CEOs. However, to provide a clear overview, we also included the results of the family CEOs for the same models that were significant for the group of nonfamily CEOs. In this study, we do not posit a strict causal relationship between CEO personality traits and firm performance; instead, the emphasis will center on the association between variables.

The CCA produces multivariate "canonical" functions that maximize the correlation between two composite variables (Thompson, 1984). The number of canonical functions is determined by the number of variables in the smaller set. In this case, there are two: ROA and ROE. Each function is independent (orthogonal) from the others to ensure that they represent different relationships among the sets of dependent and independent variables (Stewart \& Love, 1968). Hair et al. (1998) suggest using three criteria to choose which canonical functions to interpret. These three criteria are (i) the level of significance; (ii) the magnitude of the canonical correlation; and (iii) a redundancy measure for the percentage of variance accounted for from the two datasets, such as a multiple regression's $\mathrm{R}^{2}$ statistic. The level of significance is most widely assessed by observing the Wilk's lambda and its corresponding Ftest; a significance level of 0.05 is generally considered to be the acceptable minimum for interpretation (Hair et al., 1998). For the magnitude of the canonical correlation, Hair et al. 
(1998) suggest that a multivariate function should have a canonical correlation of 0.30 or above. Finally, a redundancy coefficient of approximately $10 \%$ is necessary to support the meaningfulness of the results (Sherry \& Henson, 2005). In Table 4, we report those canonical functions that satisfied all three criteria and thus could be meaningfully interpreted.

$$
\text { ***Insert Table } 4 \text { about here*** }
$$

Having determined the statistically significant functions, our attention shifts to interpreting the results. Most of the literature prefers the use of canonical loadings or crossloadings in interpreting canonical functions (Hair et al., 1998; Thompson, 1991). We report both loadings and cross-loadings in Table 4; however, for the interpretation, we have used the cross-loadings, as these provide a more direct measure of the dependent-independent variable relationship (Hair et al., 1998; Thompson, 1984). The absolute value of the cross-loadings for any variable should be 0.30 or better to be considered an important contributing variable to the function (Lambert \& Durand, 1975). A positive cross-loading indicates a positive association between a variable and a function and vice versa. Significant cross-loadings are underlined in Table 4 for emphasis and clarity.

For the group of nonfamily CEOs, data in the first CCA model's "predictors set" show that the subscales "controlling", "outspoken", and "independent minded" are negatively associated with firm performance (two-year average industry-adjusted ROA and ROE). Loadings associated with these two variable sets were both significant $(>0.30)$ and negative. Moreover, the canonical correlation coefficient of 0.78 between the two sets of variables suggests a rather strong association between those personality traits and firm financial performance. For the group of family CEOs, no significant findings were obtained.

For the group of nonfamily CEOs, in the second and third CCA models, the subscale "democratic" is significantly positively associated with firm performance (industry-adjusted ROA one year after recruitment of the CEO as well as the three-year average industry- 
adjusted ROA and ROE), and the subscale "caring" is significantly negatively associated with firm performance (three-year average industry-adjusted ROA and ROE). For the group of family CEOs, no significant findings were obtained.

In conclusion, our findings reveal several personality traits of nonfamily CEOs that are significantly associated with firm performance. For family CEOs, we find no such indications. Therefore, hypothesis 4 is supported, although it is surprising that none of the personality traits of family CEOs are significantly linked with firm performance.

\section{Discussion}

A growing body of work, often drawing on upper echelons theory, has highlighted that the CEO's personality is reflected in the strategic decisions, structure, and performance of the organization he/she leads (e.g., Herrmann \& Nadkarni, 2014; Nadkarni \& Herrmann, 2010; Ou, Waldman, \& Peterson, 2018; Peterson et al., 2003). Although personality traits have been identified as critical characteristics of all executives and as essential to understanding firm strategy and performance (Hambrick, 2007), CEO personality is largely unexplored in extant family business research. The first aim of this study was to examine how nonfamily CEOs and family CEOs differ in terms of their personalities. The findings suggest a very balanced personality profile for nonfamily CEOs and a rather strong-willed personality profile for family CEOs. Moreover, our results indicate that nonfamily and family CEOs significantly differ with respect to nine personality traits: independent minded, democratic, data rational, behavioral, detail conscious, conscientious, relaxed, worrying, and trusting. Our findings, however, were not able to confirm that nonfamily CEOs are significantly less controlling and less forward thinking than family CEOs, calling into question some assumptions in the literature about how family CEOs and nonfamily CEOs differ. The second aim of the study was to explore whether and how the personality traits of nonfamily CEOs and family CEOs relate to the financial performance of family firms. While we found that the personalities of 
nonfamily CEOs relate to firm performance, we were surprised to find no significant association for the personalities of family CEOs. The findings have implications for both theory and practice.

Our study contributes to the family business literature in several ways. We offer a fresh new perspective on the debate about nonfamily vs. family CEOs and thereby alter the way in which differences between the two CEO types are commonly viewed. We argue that family kinship alone cannot fully explain or predict the differences between nonfamily and family CEOs and that we must incorporate their personalities.

Our findings add to our knowledge on family and nonfamily CEOs and provide a deeper understanding of prior work. Blumentritt et al. (2007) and Hall and Nordqvist (2008) contend that nonfamily CEOs need to develop a deep understanding of the family's goals and values, as this helps them to balance business and family objectives and to align with the owning family. Moreover, Nordqvist (2012) refers to these nonfamily CEOs as "Simmelian strangers", actors who strike a balance between distance and closeness in their interactions with others. That balance, in turn, gives other actors a sense of objectivity and confidence that fosters an exchange of information. Our study adds to these discussions by revealing why nonfamily CEOs can be proficient in striking a balance between family goals and business goals. Our findings show that nonfamily CEOs' scores on the subscales related to "emotional" and "rational" personality traits are well balanced. Nonfamily CEOs are more rational, evaluative and persuasive, but they are also less independent minded, more democratic and more behavioral. This suggests that although nonfamily CEOs are likely to pursue a sound business agenda and will try to convince the family to support that agenda (more data rational, evaluative, persuasive), they will probably also heed family issues (more behavioral and more democratic) and sacrifice some of their ideas to compromise with the family when needed (less independent minded). 
Although we did not study co-CEO structures (i.e., when a family $\mathrm{CEO}$ and a nonfamily CEO share the same CEO title and responsibility for developing firm strategy at the same time), our study may also provide an additional explanation for the finding of Miller et al. (2014) that co-CEO structures are detrimental to family firm performance. Miller et al. (2014) explain their finding by arguing that nonfamily CEOs may contribute less to firm performance when they must battle to offset family co-CEOs' excessive emphasis on socioemotional goals. We find that family CEOs are highly independent minded and significantly less democratic, suggesting that they prefer to make decisions alone and may disregard the nonfamily CEO's input. Additionally, our results show that family CEOs are extremely competitive individuals, a characteristic that may engender a "win-lose attitude" towards the nonfamily CEO. Thus, given the dominant personality of the family CEO, coCEO structures may create tensions and conflicts with negative organizational consequences.

Nonfamily CEOs are further reported to have a flatter reporting structure and a more participatory leadership style compared to family CEOs (Mullins \& Schoar, 2016). Our study suggests that this difference in management style might be induced by the difference in their personality traits. Nonfamily CEOs are less independent minded, more democratic and more trusting of others, which explains why they are more likely to delegate and include others in their decision making. By contrast, family CEOs are highly independent minded, less democratic and less trusting of others, which causes them to be less likely to delegate or involve others in their decision making.

Furthermore, our study calls into question the assumption that family CEOs are more long-term oriented than nonfamily CEOs (James, 1999; Le Breton-Miller \& Miller, 2006). In contrast to the common depiction of nonfamily CEOs as merely focused on short-term financial performance, our findings suggest that nonfamily CEOs also tend to be forward thinking. As Hernandez (2012) shows that a long-term orientation can lead to stewardship 
behavior, this result may help substantiate the idea that nonfamily CEOs are also able to display stewardship behavior towards the family firm (Huybrechts et al., 2013). The greater long-term orientation of family firms frequently advocated in literature (e.g., Zahra, Hayton, \& Salvato, 2004) might therefore not be dependent on the family or nonfamily nature of the CEO. Our findings further indicate that not only family CEOs but also nonfamily CEOs like to be in control. Taking into account Mullins and Schoar's (2016) finding that nonfamily CEOs can experience limited freedom, this result suggests that nonfamily CEOs might become frustrated when they cannot act on their tendency to take charge within their assigned role.

Our study provides valuable new insights into the performance debate surrounding nonfamily vs. family CEOs. Previous research has shown that the performance effects of nonfamily and family CEOs are influenced by the governance and ownership contexts of the family business (e.g., Blumentritt et al., 2007; Miller et al., 2013, 2014). We add another variable to the performance debate, as we find that for nonfamily CEOs, personality seems to matter for firm performance. The nonfamily CEO personality traits "controlling", "outspoken", and "independent minded" seem to be detrimental to firm performance. However, being "democratic" seems to support the performance of the nonfamily CEO. These findings support the observations of Blumentritt et al. (2007) and Hall and Nordqvist (2008) that successful nonfamily CEO engagements are characterized by individuals who show some level of consideration for the family and remain sensitive to the social and cultural context of the family firm. However, our results add an important nuance to this conclusion, as we also find that being "caring" is negatively related to firm performance. Being sympathetic and becoming involved in the family's problems might cause the nonfamily CEO to prioritize the well-being of the family at the expense of sound business performance. This finding further 
clarifies the idea of successful nonfamily CEOs being able to balance family issues with business (Blumentritt et al., 2007; Nordqvist, 2012).

In this study, the personality traits of family CEOs do not seem to be associated with firm financial performance. We would like to offer some possible explanations for this surprising finding. First, family CEOs are said to pursue not only firm financial performance but also family-centered, socioemotional goals (Berrone, Cruz, \& Gómez-Mejía, 2012; Gómez-Mejía et al., 2007). Family CEOs are believed to balance these two types of goals, aiming for an overall satisfactory outcome that satisfies both goals sufficiently rather than maximizing one or the other (Martin \& Gómez-Mejía, 2016). Therefore, it is reasonable to presume that family CEO personality affects a multifaceted outcome that includes both financial and nonfinancial aspects (e.g., family well-being, family cohesion, employee wellbeing, firm reputation) (Holt, Pearson, Carr, \& Barnett, 2017; Yu, Lumpkin, Sorenson, \& Brigham, 2012). Moreover, the weight given to each of the goals is likely firm-idiosyncratic, with some firms tilting more towards a business-first family enterprise and some resembling a more family-first type of firm (Holt et al., 2017). Finding an effect of family CEO personality on just one of these aspects - in our case, firm financial performance - without attending to the others, can therefore be very difficult. On the other hand, as one of the main tasks of nonfamily CEOs is to improve and ensure the firm's financial performance (e.g., Blumentritt et al., 2007; Chittoor \& Das, 2007; Mullins \& Schoar, 2016), their personality might be particularly reflected in this type of outcome.

Second, we speculate that the "too-much-of-a-good-thing" phenomenon (Smith, Hill, Wallace, Recendes, \& Judge, 2018) may also partly explain the lack of significance between some personality traits and firm performance. Indeed, some papers (e.g., Carter et al., 2014) reported that too much of a personality trait may be counterproductive, suggesting that there may exist an optimal level of some personality traits, and this level will be reflected in an 
inverted-U shaped relationship (Smith et al., 2018). Future research should use larger samples to explore the possibility of such nonlinear relationships between the personality traits of family and nonfamily CEOs and firm outcomes.

Finally, our research contributes to the upper echelons theory in several ways. A central premise of upper echelons theory is that CEOs' personalities greatly influence their interpretations of the situations they face and, in turn, affect organizational performance (Hambrick, 2007). While the results of our study show that the personalities of nonfamily CEOs indeed matter for firm financial performance, thus confirming upper echelons theory, they revealed no such indications for family CEOs. This finding suggests that there are certain types of CEOs, in our study family CEOs, for whom upper echelons theory is less predictive of firm financial performance. From these results, it can be derived that when studying family businesses, the family or nonfamily nature of the CEO may be an important moderator that affects the predictive strength of upper echelons theory. As argued above, we interpret the importance of this moderator as the result of the different weights that the two types of CEOs assign to different outcomes (i.e., family CEOs value family-centered noneconomic goals in addition to financial performance). Future research may therefore investigate whether CEO goals are yet another, more general, moderator that impacts the predictions of upper echelons theory.

Our results also have implications for the concept of managerial discretion (i.e., latitude of action), which has been introduced as an important moderator affecting the predictive power of upper echelons theory. The dominant idea in upper echelons theory is that the more managerial discretion CEOs have, the more their personalities matter for performance (Hambrick, 2007). Our results do not confirm this idea. Although we did not measure the level of managerial discretion, it is reasonable to presume that family CEOs who are owners of the firm have more managerial discretion than do nonfamily CEOs (Mullins \& 
Schoar, 2016). Thus, following the predictions of upper echelons theory, family CEOs' personalities should be reflected in performance more than the personalities of nonfamily CEOs. Yet, in contrast to our nonfamily CEO findings, we find no significant associations between family CEOs' personalities and firm financial performance. These results raise the question of whether the moderating effect of managerial discretion is by itself dependent on the presence of other conditions. Future research may find it fruitful to investigate this idea.

Our results have important implications for practice. The results indicate that family CEOs have a very dominant personality. For example, if a retiring family CEO hires a nonfamily CEO but still assumes a highly active owner role in the firm on a day-to-day basis, careful attention should be paid to the dynamics of the working relationship between the two. The dominant personality of the retired family CEO might prevent the nonfamily CEO from fully engaging in his/her role and might consequently complicate the succession process. In instances where the retired family CEO remains highly active in the firm, it may be very helpful to work with a coach or other type of third party who can act as a buffer between the two actors. A coach can, for example, mitigate potential competitive behavior by reminding the retired family CEO that he/she and the nonfamily CEO are on the same team and that the competition is outside the firm. Our study also suggests that CEO personality might be another relevant criterion for recruitment, along with CEO education, experience, and social network. As personality allows the prediction of behavior, owning families should carefully consider performing a personality assessment before hiring a nonfamily CEO. Given that nonfamily CEO personalities have implications for firm performance, a personality assessment might increase the probability that the most appropriate person is selected for the job.

The findings and limitations of this study provide fruitful avenues for future research. First, although our sample size of 44 CEOs is acceptable and reflects common practice in 
studies on CEO personality (see also: Berson et al., 2008; O'Reilly et al., 2014; Peterson et al., 2003), it is a legitimate cause for caution in interpreting and generalizing the results of our study. The second reason to exercise caution in generalizing from this study involves the type of organizations studied. Our study relies on a group of private family firms characterized by high family ownership and involvement. Moreover, our sample probably reflects professionalizing private family firms as they have cooperated with an external consultancy firm to select their CEO (Gedajlovic et al., 2004). Consequently, there may be some qualifications to our findings. The personality profiles found in this study might be associated with the specific type of family firms in our sample, as organizations of a particular sort attract people of a particular sort and vice versa (Gardner, Reithel, Cogliser, Walumbwa, \& Foley, 2012). Our study does not intend to present an "ideal or universal" personality profile for the nonfamily or family CEO. We therefore believe it is vital for subsequent researchers to conduct studies on a larger sample of family firms to uncover the broader spectrum of nonfamily and family CEO personality types and to assess their fit or association with different types of family firms. In doing so, future research could consider other boundary conditions and investigate whether certain personality traits of the family firm CEO relate differently to family firm performance depending on firm industry, size, age, generation, and strategic posture.

Second, in examining the effect of CEO personality, we focused on firm financial performance as our main dependent variable. Future research could explore how family vs. nonfamily CEO personality relates to other family firm outcomes (Holt et al., 2017; Yu et al., 2012), such as socioemotional wealth preservation, the initiation and implementation of strategic change (e.g., Herrmann \& Nadkarni, 2014), and strategic flexibility (e.g., Nadkarni \& Herrmann, 2010). 
Next to the abovementioned moderators (e.g., CEO goals, managerial discretion), future research may wish to consider several mediators that connect CEO personality to firm performance. Research by Ou et al. (2018) and Peterson et al. (2003) has indicated that top management team dynamics can be an important mediator between CEO personality and firm performance. In our context, for example, the negative relation between controlling nonfamily CEOs and firm performance might be (partially) explained by the CEO's effect on the top management team, as the CEO's being too dominant might prevent top management team members from contributing to the decision making process of the firm.

Another potential mediator between nonfamily CEO personality and firm performance could be the degree to which the nonfamily CEO and the owning family are able to maintain a shared vision for the firm. Nonfamily CEOs who are more democratic might be able to understand the family's goals and values better, helping them to contribute successfully to family firm performance.

The family firm's culture can also be a critical mediator between CEO personality and organizational performance. Indeed, several studies have demonstrated that certain CEO personality traits may be associated with different types of organizational cultures, which in turn are differentially associated with subsequent firm performance (e.g., Berson et al., 2008; O'Reilly et al., 2014). Schein (1995) argues that founder CEOs create organizational culture through their personalities. On the other hand, research suggests that nonfamily CEOs should adapt to the culture of the family firm (e.g., Blumentritt et al., 2007; Hall \& Nordqvist, 2008). Therefore, an interesting question for future research would be whether a nonfamily CEO's personality can influence the culture of the family firm, and whether and how culture mediates the relationship between CEO personality and family firm performance. Are there differences in the mediating role of culture in the case of family vs. nonfamily CEOs? 
Furthermore, strategic decision processes, strategic actions, and strategic change are other mechanisms through which CEO personality influences firm performance (Herrmann \& Nadkarni, 2014; Nadkarni \& Herrmann, 2010). Scholars could explore how the personality profiles found in this study relate to the strategy of the family firm, and to subsequent family firm performance. An interesting research question would be whether, compared to family CEOs, nonfamily CEOs, given their balanced personality profiles, promote greater strategic flexibility and change, which in the end improves firm performance.

Future research may also wish to explore whether particular personality traits, or a combination thereof, are associated with a higher likelihood of displaying agency (individualistic, self-serving) or stewardship (collectivistic, pro-organizational) behavior, or a mix of both, and how that behavior impacts performance or a multifaceted outcome. This research avenue likely has the potential to paint a more nuanced portrait about when to expect which type of behavior (agency/stewardship) of a family CEO or a nonfamily CEO, and move our field beyond simplistic dichotomies such as family CEOs as stewarding principals and nonfamily CEOs as self-serving agents.

Finally, the differences in personality profiles found in this study may also inspire future research into the selection processes of the family firm CEO. It would be interesting to investigate whether family firms looking for a nonfamily CEO seek common personality traits, and if so, why? For example, future research may wish to explore the possibility that family owners purposefully seek a very balanced nonfamily CEO personality profile because such a profile would allow family owners best to continue pursuing their mix of economic and noneconomic goals. The extant literature contends that choosing a family CEO is the best option for preserving and enhancing the SEW of the family (Gómez-Mejía et al., 2007; Naldi, Cennamo, Corbetta, \& Gómez-Mejía, 2013). However, in light of the above reasoning, future research needs to examine this idea more carefully and investigate whether family 
firms/owners who seek nonfamily CEOs are less, equally or more concerned with noneconomic goals, and under what conditions.

Likewise, the strong-willed personality profile of family CEOs that we found in our sample calls for more research on how family CEOs are precisely chosen from a pool of relatives, and how the interplay between the personalities of incumbents and successors shape intrafamily succession processes. Indeed, in contrast to nonfamily CEOs who are hired, family CEOs are chosen by succession. Could it be that dominant, strong-willed family members are more likely to rise to the top, sometimes at the expense of equally or even more capable family members who possess different personality profiles? And if so, why? One possible explanation that could be further explored is that strong-willed family members readily perceive themselves as $\mathrm{CEO}$ successor candidate and signal more explicitly and confidently to incumbents that they are attracted to the CEO leadership role. Incumbent family firm leaders may interpret this signaling as "more capable" to ensure family firm continuity and preserve/enhance SEW compared to other family successor-candidates with different personality profiles, and therefore ultimately choose these dominant individuals as the best family CEO successors. Chabris and Simons (2010) talk in this regard about the everyday illusion of confidence. Individuals with dominant, strong-willed personalities tend to speak early, often and most powerfully. They thereby display greater self-confidence. Because of the illusion of confidence, others are inclined to take their self-confidence as an indication of competence, even if this is not actually the case. More generally, future research may wish to explore how interpretations of personality (in terms of social perception) and everyday illusions and cognitive biases influence the selection processes of the family firm CEO.

In conclusion, we have studied how nonfamily CEOs and family CEOs differ in terms of their personalities and how their personality traits relate to the financial performance of 
family firms. We hope our study will inspire future research on CEO personality in family firms. 


\section{References}

Allport, G. W. (1961). Pattern and growth in personality. Oxford: Holt, Reinhart \& Winston.

Barnett, M. L., \& Salomon, R. M. (2012). Does it pay to be really good? Addressing the shape of the relationship between social and financial performance. Strategic Management Journal, 33(11), 1304-1320.

Barrett, P., Kline, P., Paltiel, L., \& Eysenck, H. J. (1996). An evaluation of the psychometric properties of the concept 5.2 Occupational Personality Questionnaire. Journal of Occupational and Organizational Psychology, 69(1), 1-19.

Barth, E., Gulbrandsen, T., \& Schønea, P. (2005). Family ownership and productivity: The role of owner-management. Journal of Corporate Finance, 11(1/2), 107-127.

Bartram, D. (2005). The Great Eight competencies: A criterion-centric approach to validation. Journal of Applied Psychology, 90(6), 1185-1203.

Bartram, D. (2007). Increasing validity with forced choice criterion measurement formats. International Journal of Selection and Assessment, 15(3), 263-272.

Bartram, D. (2012). Stability of OPQ32 personality constructs across languages, cultures, and countries. In A. M. Ryan, F. T. L. Leong, \& F.L. Oswald (Eds.), Conducting multinational research: Applying organizational psychology in the workplace (pp. 59-89). Washington, DC: American Psychological Association.

Bartram, D. (2013). Scalar equivalence of OPQ32: Big Five profiles of 31 countries. Journal of CrossCultural Psychology, 44(1), 61-83.

Bartram, D., \& Brown, A. (2004). Online testing: Mode of administration and the stability of OPQ 32i scores. International Journal of Selection and Assessment, 12(3), 278-284.

Bartram, D., \& Brown, A. (2005). Five factor model (Big Five) OPQ32 report: OPQ32 Technical manual supplement. Surrey: Thames Ditton.

Bartram, D., Brown, A., Fleck, S., Inceoglu, I., \& Ward, K. (2006). OPQ32 Technical Manual 2006 version 2.0. Ditton, UK: Thames Ditton.

Beaujouan, Y. (2000). The convergence of the factorial structure of the OPQ (Occupational Personality Questionnaire) towards the Five Factor Model, in seven countries. European Review of Applied Psychology, 50(4), 349-357.

Bennedsen, M., Nielsen, K. M., Pérez-González, F., \& Wolfenzon, D. (2007). Inside the family firm: The role of families in succession decisions and performance. The Quarterly Journal of Economics, 122(2), 647-691.

Berrone, P., Cruz, C., \& Gómez-Mejía, L. R. (2012). Socioemotional wealth in family firms: Theoretical dimensions, assessment approaches, and agenda for future research. Family Business Review, 25(3), 258-279.

Berson, Y., Oreg, S., \& Dvir, T. (2008). CEO values, organizational culture and firm outcomes. Journal of Organizational Behavior, 29(5), 615-633.

Binacci, M., Peruffo, E., Oriani, R., \& Minichilli, A. (2016). Are all non-family managers (NFMs) equal? The impact of NFM characteristics and diversity on family firm performance. Corporate Governance: An International Review, 24(6), 569-583.

Block, J. (2011). How to pay nonfamily managers in large family firms: A principal—agent model. Family Business Review, 24(1), 9-27.

Blumentritt, T. P., Keyt, A. D., \& Astrachan, J. H. (2007). Creating an environment for successful nonfamily CEOs: An exploratory study of good principals. Family Business Review, 20(4), 321-335.

Bono, J. E., \& Judge, T. A. (2004). Personality and transformational and transactional leadership: A meta-analysis. Journal of Applied Psychology, 89(5), 901-910.

Buyl, T., Boone, C., \& Hendriks, W. (2014). Top management team members' decision influence and cooperative behaviour: An empirical study in the information technology industry. British Journal of Management, 25(2), 285-304.

Buyl, T., Boone, C., Hendriks, W., \& Matthyssens, P. (2011). Top management team functional diversity and firm performance: The moderating role of CEO characteristics. Journal of Management Studies, 48(1), 151-177. 
Cannella, A. A., Park, J.-H., \& Lee, H.-U. (2008). Top management team functional background diversity and firm performance: Examining the roles of team member colocation and environmental uncertainty. Academy of Management Journal, 51(4), 768-784.

Cannella, A. A., \& Shen, W. (2001). So close and yet so far: Promotion versus exit for CEO heirs apparent. Academy of Management Journal, 44(2), 252-270.

Carpenter, M. A., \& Sanders, W. (2002). Top management team compensation: The missing link between CEO pay and firm performance? Strategic Management Journal, 23(4), 367-375.

Carrasco-Hernandez, A., \& Sánchez-Marín, G. (2007). The determinants of employee compensation in family firms: Empirical evidence. Family Business Review, 20(3), 215-228.

Carter, N. T., Dalal, D. K., Boyce, A. S., O’Connell, M. S., Kung, M-C., \& Delgado, K. M. (2014). Uncovering curvilinear relationships between conscientiousness and job performance: How theoretically appropriate measurement makes an empirical difference. Journal of Applied Psychology, 99(4), 564-586.

Chabris, C. F. \& Simons, D. J. (2010). The invisible gorilla, and other ways our intuitions deceive us. New York, NY: Crown.

Chang, S. J., \& Shim, J. (2015). When does transitioning from family to professional management improve firm performance? Strategic Management Journal, 36(9), 1297-1316.

Chittoor, R., \& Das, R. (2007). Professionalization of management and succession performance-A vital linkage. Family Business Review, 20(1), 65-79.

Chrisman, J. J., Chua, J. H., \& Sharma, P. (2005). Trends and directions in the development of a strategic management theory of the family firm. Entrepreneurship Theory and Practice, 29(5), 555-576.

Chrisman, J. J., Memili, E., \& Misra, K. (2014). Nonfamily managers, family firms, and the winner's curse: The influence of noneconomic goals and bounded rationality. Entrepreneurship Theory and Practice, 38(5), 1103-1127.

Chua, J. H., Chrisman, J. J., \& Sharma, P. (2003). Succession and nonsuccession concerns of family firms and agency relationship with nonfamily managers. Family Business Review, 16(2), 89107.

Cohen, J. (2013). Statistical power analysis for the behavioral sciences. New York: Lawrence Erlbaum Publishers.

Colbert, A. E., Barrick, M. R., \& Bradley, B. H. (2014). Personality and leadership composition in top management teams: Implications for organizational effectiveness. Personnel Psychology, 67(2), 351-387.

Cucculelli, M., \& Micucci, G. (2008). Family succession and firm performance: Evidence from Italian family firms. Journal of Corporate Finance, 14(1), 17-31.

Dyer, W. G. (1989). Integrating professional management into a family owned business. Family Business Review, 2(3), 221-235.

Feist, J., Feist, G. J., \& Roberts, T-A. (2017). Theories of personality. New York: McGraw-Hill.

Finkelstein, S., Hambrick, D. C., \& Cannella, A. A. (2009). Strategic leadership: Theory and research on executives, top management teams, and boards. New York, NY: Oxford University Press.

Fisher, S. G., Hunter, T., \& Macrosson, W. (2001). A validation study of Belbin's team roles. European Journal of Work and Organizational Psychology, 10(2), 121-144.

Funder, D. C. (2001). Accuracy in personality judgment: Research and theory concerning an obvious question. In B. W. R. R. Hogan (Ed.), Decade of behavior. Personality psychology in the workplace (pp. 121-140). Washington, DC, US: American Psychological Association.

Gardner, W. L., Reithel, B. J., Cogliser, C. C., Walumbwa, F. O., \& Foley, R. T. (2012). Matching personality and organizational culture: Effects of recruitment strategy and the Five-Factor Model on subjective person-organization fit. Management Communication Quarterly, 26(4), $585-622$.

Gedajlovic, E., \& Carney, M. (2010). Markets, hierarchies, and families: Toward a transaction cost theory of the family firm. Entrepreneurship Theory and Practice, 34(6), 1145-1172.

Gedajlovic, E., Lubatkin, M. H., \& Schulze, W. S. (2004). Crossing the threshold from founder management to professional management: A governance perspective. Journal of Management Studies, 41(5), 899-912. 
Gómez-Mejía, L. R., Haynes, K. T., Núñez-Nickel, M., Jacobson, K. J. L., \& Moyano-Fuentes, J. (2007). Socioemotional wealth and business risks in family-controlled firms: Evidence from Spanish olive oil mills. Administrative Science Quarterly, 52(1), 106-137.

Hair, J. F., Anderson, R. E., Tatham, R. L., \& Black, W. C. (1998). Multivariate data analysis. Upper Saddle River, NJ: Prentice Hall.

Hall, A., \& Nordqvist, M. (2008). Professional management in family businesses: Toward an extended understanding. Family Business Review, 21(1), 51-69.

Hambrick, D. C. (2007). Upper echelons theory: An update. Academy of Management Review, 32(2), 334-343.

Hambrick, D. C., Finkelstein, S., \& Mooney, A. C. (2005). Executives sometimes lose it, just like the rest of us. Academy of Management Review, 30(3), 503-508.

Hambrick, D. C., \& Mason, P. A. (1984). Upper echelons: The organization as a reflection of its top managers. Academy of Management Review, 9(2), 193-206.

Henderson, A. D., Miller, D., \& Hambrick, D. C. (2006). How quickly do CEOs become obsolete? Industry dynamism, CEO tenure, and company performance. Strategic Management Journal, 27(5), 447-460.

Hernandez, M. (2012). Toward an understanding of the psychology of stewardship. Academy of Management Review, 37(2), 172-193.

Herrmann, P., \& Nadkarni, S. (2014). Managing strategic change: The duality of CEO personality. Strategic Management Journal, 35(9), 1318-1342.

Holt, D. T., Pearson, A. W., Carr, J. C., \& Barnett, T. (2017). Family firm (s) outcomes model: Structuring financial and nonfinancial outcomes across the family and firm. Family Business Review, 30(2), 182-202.

Hunthausen, J. M., Truxillo, D. M., Bauer, T. N., \& Hammer, L. B. (2003). A field study of frame-ofreference effects on personality test validity. Journal of Applied Psychology, 88(3), 545-551.

Huybrechts, J., Voordeckers, W., \& Lybaert, N. (2013). Entrepreneurial risk taking of private family firms: The influence of a nonfamily CEO and the moderating effect of CEO tenure. Family Business Review, 26(2), 161-179.

Jaccard, J. J. (1974). Predicting social behavior from personality traits. Journal of Research in Personality, 7(4), 358-367.

James, H. S. (1999). Owner as manager, extended horizons and the family firm. International Journal of the Economics of Business, 6(1), 41-55.

Judge, T. A., Bono, J. E., Ilies, R., \& Gerhardt, M. W. (2002). Personality and leadership: A qualitative and quantitative review. Journal of Applied Psychology, 87(4), 765-780.

Karaevli, A. (2007). Performance consequences of new CEO 'Outsiderness': Moderating effects of pre-and post-succession contexts. Strategic Management Journal, 28(7), 681-706.

Kets de Vries, M. F. (1985). The dark side of entrepreneurship. Harvard Business Review, 85(6), 160167.

Lambert, Z. V., \& Durand, R. M. (1975). Some precautions in using canonical analysis. Journal of Marketing Research, 12(4), 468-475.

Le Breton-Miller, I., \& Miller, D. (2006). Why do some family businesses out-compete? Governance, long-term orientations, and sustainable capability. Entrepreneurship Theory and Practice, 30(6), 731-746.

Lievens, F., Harris, M. M., Van Keer, E., \& Bisqueret, C. (2003). Predicting cross-cultural training performance: The validity of personality, cognitive ability, and dimensions measured by an assessment center and a behavior description interview. Journal of Applied Psychology, 88(3), 476-489.

Ling, Y., Simsek, Z., Lubatkin, M. H., \& Veiga, J. F. (2008). The impact of transformational CEOs on the performance of small-to medium-sized firms: Does organizational context matter? Journal of Applied Psychology, 93(4), 923-934.

Marler, L. E., Botero, I. C., \& De Massis, A. (2017). Succession-related role transitions in family firms: The impact of proactive personality. Journal of Managerial Issues, 29(1), 57-81.

Martin, G., \& Gómez-Mejía, L. R. (2016). The relationship between socioemotional and financial wealth: Re-visiting family firm decision making. Management Research: Journal of the Iberoamerican Academy of Management, 14(3), 215-233. 
Matthews, G., Stanton, N., Graham, N. C., \& Brimelow, C. (1990). A factor analysis of the scales of the Occupational Personality Questionnaire. Personality and Individual Differences, 11(6), 591-596.

Mehrotra, V., Morck, R., Shim, J., \& Wiwattanakantang, Y. (2013). Adoptive expectations: Rising sons in Japanese family firms. Journal of Financial Economics, 108(3), 840-854.

Miller, D. (2015). A downside to the entrepreneurial personality? Entrepreneurship Theory and Practice, 39(1), 1-8.

Miller, D., Le Breton-Miller, I., Minichilli, A., Corbetta, G., \& Pittino, D. (2014). When do non-family CEOs outperform in family firms? Agency and behavioural agency perspectives. Journal of Management Studies, 51(4), 547-572.

Miller, D., Minichilli, A., \& Corbetta, G. (2013). Is family leadership always beneficial? Strategic Management Journal, 34(5), 553-571.

Mischel, W. (1993). Introduction to personality. Fort Worth, TX: Harcourt Brace Jovanovich.

Mullins, W., \& Schoar, A. (2016). How do CEOs see their role? Management philosophy and styles in family and non-family firms. Journal of Financial Economics, 119(1), 24-43.

Nadkarni, S., \& Herrmann, P. (2010). CEO personality, strategic flexibility, and firm performance: The case of the Indian business process outsourcing industry. Academy of Management Journal, 53(5), 1050-1073.

Naldi, L., Cennamo, C., Corbetta, G., \& Gómez-Mejía, L. R. (2013). Preserving socioemotional wealth in family firms: Asset or liability? The moderating role of business context. Entrepreneurship: Theory \& Practice, 37(6), 1341-1360.

Nordqvist, M. (2012). Understanding strategy processes in family firms: Exploring the roles of actors and arenas. International Small Business Journal, 30(1), 24-40.

O'Reilly, C. A., Caldwell, D. F., Chatman, J. A., \& Doerr, B. (2014). The promise and problems of organizational culture: CEO personality, culture, and firm performance. Group \& Organization Management, 39(6), 595-625.

Ones, D. S., \& Viswesvaran, C. (2001). Integrity tests and other criterion-focused occupational personality scales (COPS) used in personnel selection. International Journal of Selection and Assessment, 9(1/2), 31-39.

Ou, A. Y., Waldman, D. A., \& Peterson, S. J. (2018). Do humble CEOs matter? An examination of CEO humility and firm outcomes. Journal of Management, 44(3), 1147-1173.

Pérez-González, F. (2006). Inherited control and firm performance. The American Economic Review, 96(5), 1559-1588.

Perry, S. J., Hunter, E. M., Witt, L., \& Harris, K. J. (2010). $\mathrm{P}=\mathrm{f}$ (conscientiousness $\times$ ability): Examining the facets of conscientiousness. Human Performance, 23(4), 343-360.

Peterson, R. S., Smith, D. B., Martorana, P. V., \& Owens, P. D. (2003). The impact of chief executive officer personality on top management team dynamics: One mechanism by which leadership affects organizational performance. Journal of Applied Psychology, 88(5), 795-808.

Pittino, D., Visintin, F., \& Lauto, G. (2017). A configurational analysis of the antecedents of entrepreneurial orientation. European Management Journal, 35(2), 224-237.

Robertson, I. T., \& Kinder, A. (1993). Personality and job competences: The criterion-related validity of some personality variables. Journal of Occupational and Organizational Psychology, 66(3), 225-244.

Saville, P. (2016). From obscurity to clarity in psychometric testing: Selected works of Professor Peter Saville (World Library of Psychologists Series). London: Routledge.

Saville, P., Holdsworth, R., Nyfield, G., Cramp, L., \& Mabey, W. (1990). Occupational Personality Questionnaire Manual. Surrey, England: Saville \& Holdsworth.

Saville, P., Sik, G., Nyfield, G., Hackston, J., \& Maclver, R. (1996). A demonstration of the validity of the Occupational Personality Questionnaire (OPQ) in the measurement of job competencies across time and in separate organisations. Applied Psychology, 45(3), 243-262.

Saville, P., \& Willson, E. (1991). The reliability and validity of normative and ipsative approaches in the measurement of personality. Journal of Occupational Psychology, 64(3), 219-238.

Schein, E. H. (1995). The role of the founder in creating organizational culture. Family Business Review, 8(3), 221-238.

Schein, E. H. (2010). Organizational culture and leadership. San Francisco, CA: Jossey-Bass. 
Shen, W., \& Cannella, A. A. (2002). Revisiting the performance consequences of CEO succession: The impacts of successor type, postsuccession senior executive turnover, and departing CEO tenure. The Academy of Management Journal, 45(4), 717-733.

Sherman, R. A., Nave, C. S., \& Funder, D. C. (2010). Situational similarity and personality predict behavioral consistency. Journal of Personality and Social Psychology, 99(2), 330-343.

Sherry, A., \& Henson, R. K. (2005). Conducting and interpreting canonical correlation analysis in personality research: A user-friendly primer. Journal of Personality Assessment, 84(1), 37-48.

SHL. (2011). SHL Testhandleiding OPQ32i Nederlandstalige en Vlaamstalige Versies. Versie 1.2. Nederland: Utrecht: SHL België BV.

Simsek, Z., Jansen, J. J. P., Minichilli, A., \& Escriba-Esteve, A. (2015). Strategic leadership and leaders in entrepreneurial contexts: A nexus for innovation and impact missed? Journal of Management Studies, 52(4), 463-478.

Smith, M. B., Hill, A. D., Wallace, J. C., Recendes, T., \& Judge, T. A. (2018). Upsides to dark and downsides to bright personality: A multidomain review and future research agenda. Journal of Management, 44(1), 191-217.

Stewart, D., \& Love, W. (1968). A general canonical correlation index. Psychological Bulletin, 70(3), 160-163.

Terracciano, A., McCrae, R. R., \& Costa, P. T. (2010). Intra-individual change in personality stability and age. Journal of Research in Personality, 44(1), 31-37.

The British Psychological Society (2007). Psychological Testing Centre Test Reviews: Occupational Personality Questionnaire (OPQ32). Leicester: The British Psychological Society.

Thompson, B. (1984). Canonical correlation analysis: Uses and interpretation. Newbury Park, CA: Sage.

Thompson, B. (1991). A primer on the logic and use of canonical correlation analysis. Measurement and Evaluation in Counseling and Development, 24(2), 80-95.

Venkatraman, N., \& Ramanujam, V. (1986). Measurement of business performance in strategy research: A comparison of approaches. Academy of Management Review, 11(4), 801-814.

Vinson, G. A., Connelly, B. S., \& Ones, D. S. (2007). Relationships between personality and organization switching: Implications for utility estimates. International Journal of Selection and Assessment, 15(1), 118-133.

Westhead, P., \& Howorth, C. (2006). Ownership and management issues associated with family firm performance and company objectives. Family Business Review, 19(4), 301-316.

Yu, A., Lumpkin, G., Sorenson, R. L., \& Brigham, K. H. (2012). The landscape of family business outcomes: A summary and numerical taxonomy of dependent variables. Family Business Review, 25(1), 33-57.

Zahra, S. A., Hayton, J. C., \& Salvato, C. (2004). Entrepreneurship in family vs. non-family firms: A resource-based analysis of the effect of organizational culture. Entrepreneurship Theory and Practice, 28(4), 363-381. 
Table 1. Literature on nonfamily and family CEO personality traits

\begin{tabular}{|c|c|c|c|c|}
\hline Source & Content related to CEO personality & Corresponding OPQ personality traits & $\begin{array}{l}\text { Theoretical } \\
\text { lens }\end{array}$ & $\begin{array}{l}\text { Conceptual/ } \\
\text { empirical } \\
\text { examination of } \\
\text { personality }\end{array}$ \\
\hline $\begin{array}{l}\text { Kets de Vries } \\
(1985)\end{array}$ & $\begin{array}{l}\text { Owner-managers are achievement oriented, like to take responsibility, dislike repetitive and routine } \\
\text { work, possess high levels of energy and great degrees of perseverance and imagination. Owner- } \\
\text { managers have a bias toward action, which makes them act rather thoughtlessly. They have a need for } \\
\text { control, influence, power and authority, and have issues of dominance. They do not take kindly to } \\
\text { suggestions or orders from other people (do not accept authority/are suspicious of it). They experience } \\
\text { structure as stifling, find it very difficult to work with others in structured situations unless they created } \\
\text { the structure and the work is done on their terms. Owner-managers have little tolerance for } \\
\text { subordinates who think for themselves, have a sense of distrust, desire for applause and see things in } \\
\text { extremes. They have difficulty controlling their impulses and managing anxiety. }\end{array}$ & $\begin{array}{l}\text { Achieving, controlling, independent } \\
\text { minded, variety seeking, conscientious, } \\
\text { decisive, (non-) data rational, (non-) } \\
\text { detail conscious, (non-) rule following, } \\
\text { (non-) democratic, (non-) trusting, (non-) } \\
\text { relaxed, worrying }\end{array}$ & $\mathrm{N} / \mathrm{A}$ & Conceptual \\
\hline $\begin{array}{l}\text { Marler, Botero, } \\
\& \text { De Massis } \\
(2017)\end{array}$ & $\begin{array}{l}\text { A proactive personality of the family incumbent and family successor may or may not lead to effective } \\
\text { role transitions during the succession process depending on personality congruence. }\end{array}$ & $\begin{array}{l}\text { Proactive shows some similarities to: } \\
\text { (non-) conventional, innovative, variety } \\
\text { seeking, adaptable }\end{array}$ & N/A & Conceptual \\
\hline Miller (2015) & $\begin{array}{l}\text { Owner-managers have elevated needs for achievement, autonomy, power, control, dominance and } \\
\text { independence. They are characterized by self-confidence, vigor, aggressiveness, energy, passion, } \\
\text { optimism, self-efficacy and self-assurance. These traits, however, are Janus-faced and have } \\
\text { complementary facets, such as grandiosity, overconfidence, narcissism, hubris, aggressiveness, } \\
\text { ruthlessness, social deviance, indifference to others, obsessive behavior, mistrust, and suspicion. }\end{array}$ & $\begin{array}{l}\text { Controlling, independent minded, } \\
\text { socially confident, (non-) modest, (non-) } \\
\text { democratic, (non-) caring, worrying, } \\
\text { optimistic, (non-) trusting, vigorous, } \\
\text { achieving }\end{array}$ & N/A & Conceptual \\
\hline $\begin{array}{l}\text { Pittino, Visintin, } \\
\& \text { Lauto (2017) }\end{array}$ & $\begin{array}{l}\text { Family CEOs shape their company's entrepreneurial orientation according to their personality. Various } \\
\text { combinations of personality traits (tolerance for ambiguity and locus of control are considered) and } \\
\text { motivations may lead to entrepreneurial orientation. }\end{array}$ & $\begin{array}{l}\text { Tolerance for ambiguity shows some } \\
\text { similarities with innovative, (non-) } \\
\text { conventional, variety seeking, and } \\
\text { adaptable. }\end{array}$ & N/A & $\begin{array}{l}\text { Empirical } \\
\text { (survey-based } \\
\text { study) }\end{array}$ \\
\hline Schein (1995) & $\begin{array}{l}\text { Family CEOs tend to be intuitive in their decision making, are strong minded, have strong assumptions } \\
\text { about the nature of humans, the world, and the role their organization will play in that world. They are } \\
\text { achievement-oriented, oriented toward creating and building, and they are Self-oriented: worried about } \\
\text { their own image with a high need for "glory". They have a high need for autonomy. Family CEOs are } \\
\text { primarily intuitive and trusting of own intuitions. They adopt a long-range time horizon and are } \\
\text { holistic: able to see the total picture and patterns. They are "particularistic," in the sense of being } \\
\text { personal, involved. They are centralistic, autocratic, emotional, impatient and easily bored. } \\
\text { Nonfamily CEOs tend to base decisions on logical and rational analysis, they tend to be impersonal in } \\
\text { their interactions with others. They are primarily analytical, more cautious about intuitions and adopt a } \\
\text { short-range time horizon. Nonfamily CEOs are specific, able to see details and their consequences. } \\
\text { They are "universalistic," in the sense of seeing individuals as members of categories such as } \\
\text { employees, customers, suppliers, and so on. They are rational, participative and delegation-oriented. } \\
\text { They are unemotional, patient and persistent. }\end{array}$ & $\begin{array}{l}\text { Independent minded, controlling, data } \\
\text { rational, forward thinking, variety } \\
\text { seeking, detail conscious, relaxed, } \\
\text { worrying, democratic }\end{array}$ & N/A & Conceptual \\
\hline
\end{tabular}


Table 2. Respondent descriptives $(n=44)$

\begin{tabular}{lrr} 
Characteristics & Nonfamily CEOs (n=25) & Family CEOs (n=19) \\
\hline Respondent age & 35 & 25 \\
Min. & 65 & 54 \\
Max. & 46.28 & 38.61 \\
Mean & 6.29 & 8.34 \\
SD & & \\
Respondent gender & & $73 \%$ \\
Male & $92 \%$ & $27 \%$ \\
Female & $8 \%$ & \\
& & \\
Respondent education level & & $53 \%$ \\
Master's degree & $76 \%$ & $21 \%$ \\
Bachelor's degree & $24 \%$ & $26 \%$ \\
High school degree & $0 \%$ & \\
& & \\
Respondent education type & & $47 \%$ \\
Economic & $68 \%$ & $16 \%$ \\
Technical & $24 \%$ & $37 \%$ \\
Other & $8 \%$ & \\
\hline
\end{tabular}


Figure 1a: Relationships with people

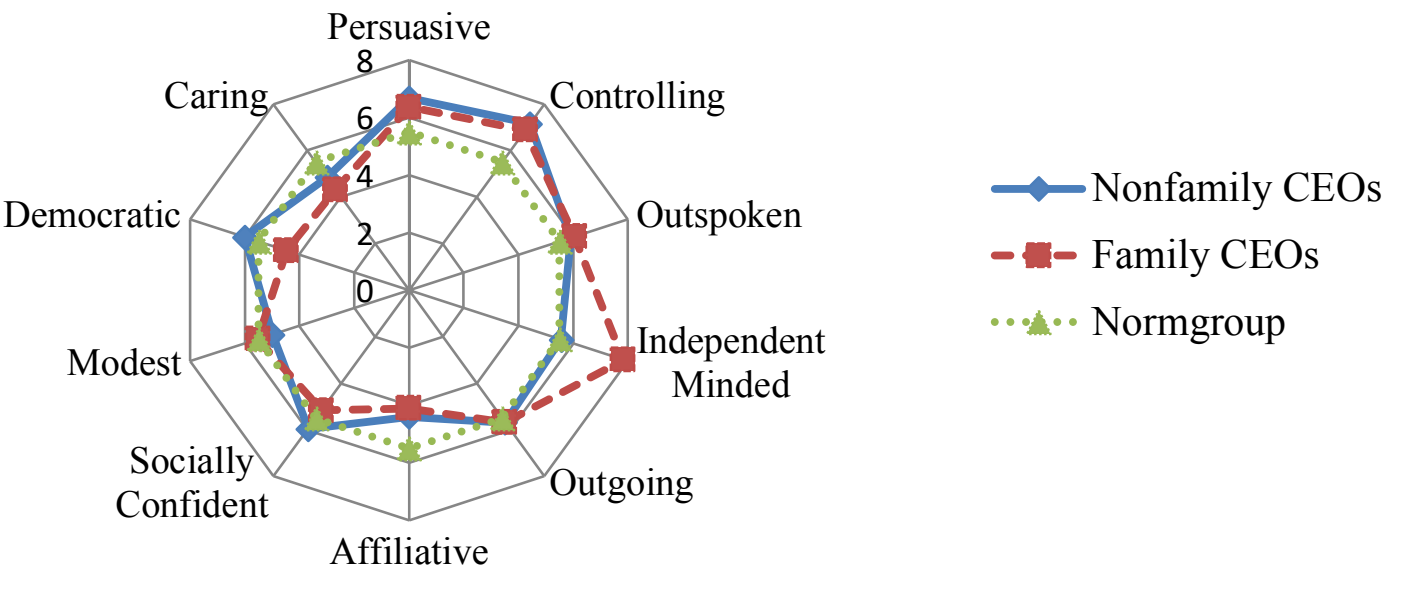

\section{Figure 1b: Various thought styles}

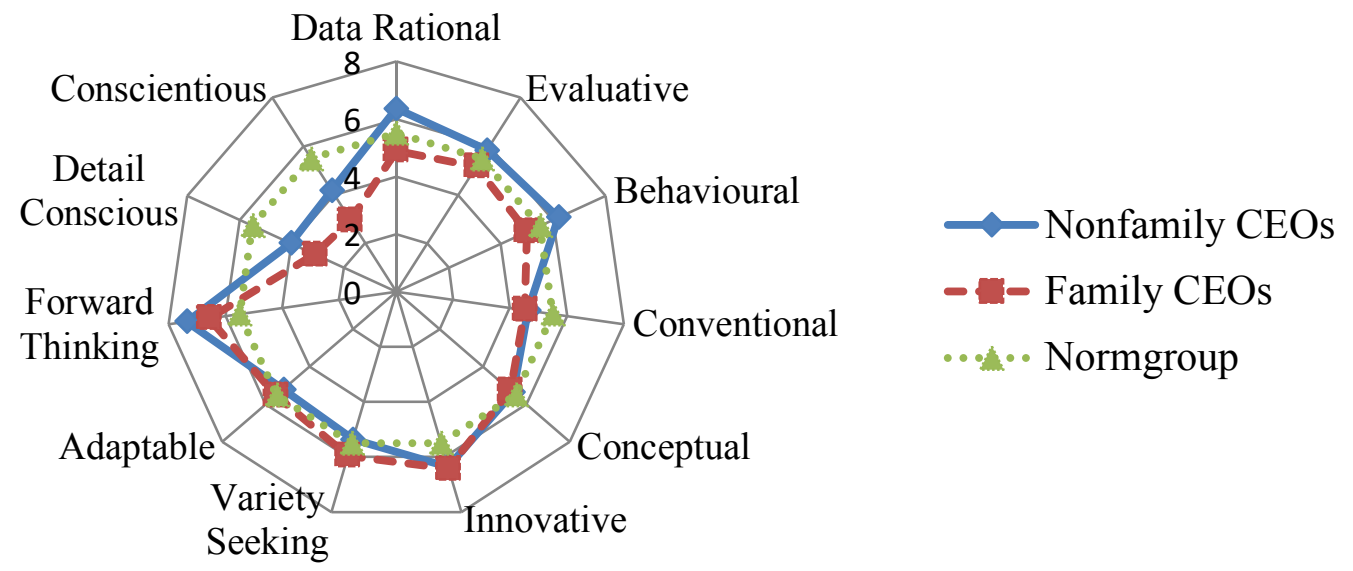

Figure 1c: Feelings and emotions

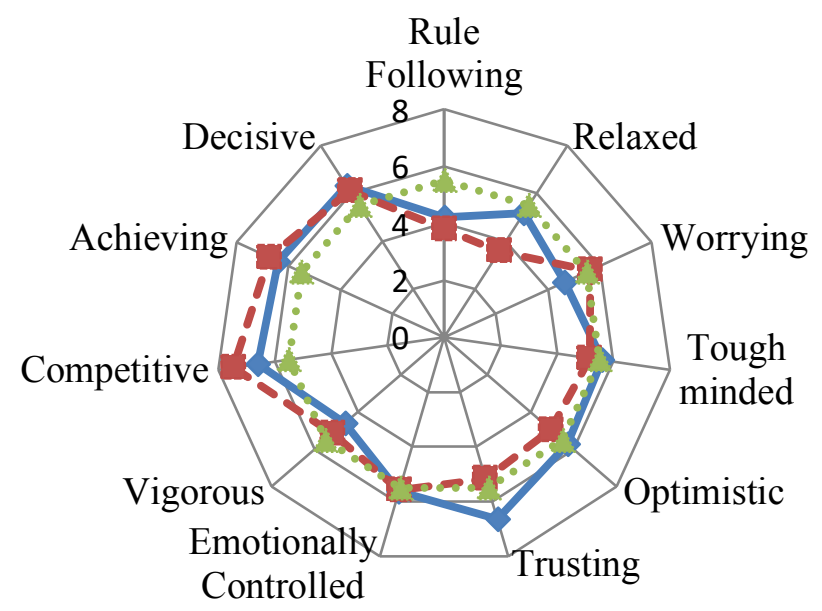

$\leadsto$ Nonfamily CEOs

- Family CEOs

..... Normgroup 
Table 3. Mean scores and results of the independent samples t-test

\begin{tabular}{|c|c|c|c|c|c|c|c|}
\hline \multirow[b]{2}{*}{ Subscales } & \multicolumn{2}{|c|}{$\begin{array}{l}\text { Nonfamily CEOs } \\
(n=25)\end{array}$} & \multicolumn{2}{|c|}{$\begin{array}{l}\text { Family CEOs } \\
(n=19)\end{array}$} & \multicolumn{3}{|c|}{ Results of the independent samples t-test } \\
\hline & Mean & $S D$ & Mean & $S D$ & $\begin{array}{l}\text { Mean } \\
\text { difference }\end{array}$ & $\begin{array}{l}\text { Std. error } \\
\text { difference }\end{array}$ & Cohen's d \\
\hline Persuasive & 6.68 & 1.406 & 6.37 & 1.640 & 0.3116 & 0.460 & -0.2040 \\
\hline Controlling & 7.16 & 1.281 & 6.89 & 1.560 & 0.2653 & 0.428 & -0.1859 \\
\hline Outspoken & 5.92 & 1.998 & 6.05 & 1.929 & -0.1326 & 0.599 & 0.0675 \\
\hline Independent Minded & 5.56 & 1.474 & 7.84 & 0.898 & $-2.2821 * * *$ & 0.384 & 1.8695 \\
\hline Outgoing & 5.68 & 1.796 & 5.68 & 1.974 & -0.0042 & 0.570 & 0.0022 \\
\hline Affiliative & 4.40 & 2.000 & 4.11 & 1.883 & 0.2947 & 0.594 & -0.1518 \\
\hline Socially Confident & 5.96 & 1.968 & 5.16 & 1.675 & 0.8021 & 0.563 & -0.4389 \\
\hline Modest & 5.00 & 1.683 & 5.53 & 1.645 & -0.5263 & 0.507 & 0.3162 \\
\hline Democratic & 6.00 & 1.871 & 4.47 & 1.982 & $1.5263^{*}$ & 0.584 & -0.7919 \\
\hline Caring & 4.84 & 2.249 & 4.32 & 1.797 & 0.5242 & 0.629 & -0.2576 \\
\hline Data Rational & 6.36 & 1.186 & 4.89 & 1.823 & $1.4653 * *$ & 0.481 & -0.9530 \\
\hline Evaluative & 5.84 & 1.650 & 5.16 & 1.951 & 0.6821 & 0.543 & -0.3775 \\
\hline Behavioral & 6.20 & 1.848 & 5.00 & 1.528 & $1.2000 *$ & 0.523 & -0.7077 \\
\hline Conventional & 4.64 & 1.524 & 4.53 & 1.429 & 0.1137 & 0.452 & -0.0770 \\
\hline Conceptual & 5.36 & 1.705 & 5.26 & 1.881 & 0.0968 & 0.543 & -0.0539 \\
\hline Innovative & 6.36 & 1.846 & 6.42 & 2.116 & -0.0611 & 0.598 & 0.0307 \\
\hline Variety Seeking & 5.36 & 1.680 & 5.95 & 1.508 & -0.5874 & 0.490 & 0.3679 \\
\hline Adaptable & 5.20 & 2.121 & 5.53 & 1.896 & -0.3263 & 0.617 & 0.1622 \\
\hline Forward Thinking & 7.36 & 1.868 & 6.58 & 2.143 & 0.7811 & 0.606 & -0.3886 \\
\hline Detail Conscious & 4.04 & 1.859 & 3.11 & 1.524 & $0.9347^{\dagger}$ & 0.525 & -0.5499 \\
\hline Conscientious & 4.16 & 1.951 & 2.95 & 1.433 & $1.2126^{*}$ & 0.532 & -0.7085 \\
\hline Rule Following & 4.20 & 1.732 & 3.79 & 1.437 & 0.4105 & 0.491 & -0.2580 \\
\hline Relaxed & 5.16 & 1.841 & 3.58 & 1.805 & $1.5811^{* *}$ & 0.556 & -0.8672 \\
\hline Worrying & 4.64 & 1.655 & 5.63 & 1.770 & $-0.9916^{\dagger}$ & 0.519 & 0.5786 \\
\hline Tough minded & 5.60 & 1.354 & 5.16 & 1.500 & 0.4421 & 0.432 & -0.3094 \\
\hline Optimistic & 5.72 & 1.646 & 4.95 & 2.147 & 0.7726 & 0.571 & -0.4039 \\
\hline Trusting & 6.64 & 1.524 & 5.16 & 2.035 & $1.4821 * *$ & 0.536 & -0.8244 \\
\hline Emotionally Controlled & 5.64 & 2.039 & 5.58 & 1.575 & 0.0611 & 0.564 & -0.0335 \\
\hline Vigorous & 4.60 & 1.555 & 5.16 & 1.864 & -0.5579 & 0.516 & 0.3251 \\
\hline Competitive & 6.60 & 1.756 & 7.47 & 1.775 & -0.8737 & 0.537 & 0.4948 \\
\hline Achieving & 6.40 & 1.633 & 6.74 & 1.485 & -0.3368 & 0.478 & 0.2158 \\
\hline Decisive & 6.32 & 1.930 & 6.11 & 2.470 & 0.2147 & 0.663 & -0.0969 \\
\hline
\end{tabular}

Note. $\dagger$ indicates significance at $\mathrm{p}<0.1 ; *$ at $\mathrm{p}<0.05 ; * *$ at $\mathrm{p}<0.01 ; * * *$ at $\mathrm{p}<0.001$ 


\begin{tabular}{|c|c|c|c|c|}
\hline \multirow[b]{2}{*}{ Variables } & \multicolumn{2}{|c|}{ Nonfamily CEOS } & \multicolumn{2}{|c|}{ Family CEOs } \\
\hline & Canonical loadings & Cross-loadings & $\begin{array}{c}\text { Canonical } \\
\text { loadings }\end{array}$ & $\begin{array}{c}\text { Cross- } \\
\text { loadings }\end{array}$ \\
\hline \multicolumn{5}{|l|}{ "Predictor set 1" } \\
\hline Persuasive & -0.1290 & -0.1009 & 0.4265 & 0.1958 \\
\hline Controlling & 0.3961 & $\underline{0.3100}$ & 0.7301 & 0.0886 \\
\hline Outspoken & 0.9544 & $\underline{0.7469}$ & -0.6017 & -0.2686 \\
\hline Independent Minded & 0.4202 & $\underline{0.3288}$ & 0.8993 & 0.1525 \\
\hline \multicolumn{5}{|l|}{ "Criterion set" } \\
\hline Two-year average industry-adjusted ROA & -0.6942 & $\underline{-0.5433}$ & -1.2174 & 0.0995 \\
\hline Two-year average industry-adjusted ROE & -0.9876 & $\underline{-0.7729}$ & 1.7389 & 0.3267 \\
\hline Canonical correlation & \multicolumn{2}{|l|}{0.7826} & \multicolumn{2}{|c|}{0.4470} \\
\hline $\mathrm{P}<$ & \multicolumn{2}{|l|}{0.00328} & \multicolumn{2}{|c|}{0.9415} \\
\hline Redundancy index & \multicolumn{2}{|c|}{$19.48 \%$} & \multicolumn{2}{|c|}{$3.54 \%$} \\
\hline \multicolumn{5}{|l|}{ "Predictor set 2" } \\
\hline Modest & 0.2787 & 0.1958 & -0.1952 & -0.1481 \\
\hline Democratic & -0.5086 & $\underline{-0.3577}$ & 1.1167 & 0.3885 \\
\hline Caring & 0.3546 & 0.2494 & -0.2580 & 0.2176 \\
\hline \multicolumn{5}{|l|}{ "Criterion set alternative 1" } \\
\hline Industry-adjusted ROA (1 year after recruitment) & -0.8948 & $\underline{-0.6293}$ & 1.5284 & 0.1838 \\
\hline Industry-adjusted ROE (1 year after recruitment) & -0.4409 & $\underline{-0.3100}$ & -1.3978 & -0.0898 \\
\hline Canonical correlation & \multicolumn{2}{|l|}{0.7033} & \multicolumn{2}{|c|}{0.4066} \\
\hline $\mathrm{P}<$ & \multicolumn{2}{|l|}{0.0441} & \multicolumn{2}{|c|}{0.8338} \\
\hline Redundancy index & \multicolumn{2}{|l|}{$9.29 \%$} & \multicolumn{2}{|c|}{$7.45 \%$} \\
\hline \multicolumn{5}{|l|}{ "Predictor set 2" } \\
\hline Modest & 0.1973 & 0.1501 & -0.2449 & -03179 \\
\hline Democratic & -0.5305 & $\underline{-0.4034}$ & 0.3927 & 0.5133 \\
\hline Caring & 0.4662 & $\underline{0.3545}$ & 0.0126 & 0.3771 \\
\hline \multicolumn{5}{|l|}{ “Criterion set alternative 2" } \\
\hline Three-year average industry-adjusted ROA & -0.9970 & $\underline{-0.7581}$ & 0.0765 & 0.4188 \\
\hline Three-year average industry-adjusted ROE & -0.8316 & $\underline{-0.6323}$ & -0.0087 & -0.3639 \\
\hline Canonical correlation & 0.7604 & & 0.5 & \\
\hline $\mathrm{P}<$ & 0.05 & & 0.47 & \\
\hline Redundancy index & $10.25 \%$ & & 15.2 & $2 \%$ \\
\hline
\end{tabular}

Note. Significant findings are underlined $(\mathrm{p}<0.05$; canonical correlation $\geq 0.3$, redundancy $\geq 10 \%$; Hair et al., 1998) 


\section{Appendix. Descriptions of the individual OPQ subscales from the OPQ technical manual (Bartram et al., 2006, p. 9-11)}

\begin{tabular}{llll}
\hline $\begin{array}{l}\text { Behavior associated with low } \\
\text { scores }\end{array}$ & Subscales & $\begin{array}{l}\text { Behavior associated with high } \\
\text { scores }\end{array}$ \\
\hline
\end{tabular}

\section{Dimension 1: Relationships with people}

\begin{tabular}{|c|c|c|}
\hline $\begin{array}{l}\text { Rarely pressures others to change } \\
\text { their views, dislikes selling, less } \\
\text { comfortable using negotiation }\end{array}$ & Persuasive & $\begin{array}{l}\text { Enjoys selling, comfortable using } \\
\text { negotiation, likes to change other } \\
\text { people's view }\end{array}$ \\
\hline $\begin{array}{l}\text { Happy to let others take charge, } \\
\text { dislikes telling people what to do, } \\
\text { unlikely to take the lead }\end{array}$ & Controlling & $\begin{array}{l}\text { Likes to be in charge, takes the } \\
\text { lead, tells others what to do, takes } \\
\text { control }\end{array}$ \\
\hline $\begin{array}{l}\text { Holds back from criticising others, } \\
\text { may not express own views, } \\
\text { unprepared to put forward own } \\
\text { opinions }\end{array}$ & Outspoken & $\begin{array}{l}\text { Freely expresses opinions, makes } \\
\text { disagreement clear, prepared to } \\
\text { criticise others }\end{array}$ \\
\hline $\begin{array}{l}\text { Accepts majority decisions, } \\
\text { prepared to follow the consensus }\end{array}$ & Independent Minded & $\begin{array}{l}\text { Prefers to follow own approach, } \\
\text { prepared to disregard majority } \\
\text { decisions }\end{array}$ \\
\hline $\begin{array}{l}\text { Quiet and reserved in groups, } \\
\text { dislikes being centre of attention }\end{array}$ & Outgoing & $\begin{array}{l}\text { Lively and animated in groups, } \\
\text { talkative, enjoys attention }\end{array}$ \\
\hline $\begin{array}{l}\text { Comfortable spending time away } \\
\text { from people, values time spent } \\
\text { alone, seldom misses the company } \\
\text { of others }\end{array}$ & Affiliative & $\begin{array}{l}\text { Enjoys others' company, likes to be } \\
\text { around people, can miss the } \\
\text { company of others }\end{array}$ \\
\hline $\begin{array}{l}\text { Feels more comfortable in less } \\
\text { formal situations, can feel awkward } \\
\text { when first meeting people }\end{array}$ & Socially Confident & $\begin{array}{l}\text { Feels comfortable when first } \\
\text { meeting people, at ease in formal } \\
\text { situations }\end{array}$ \\
\hline $\begin{array}{l}\text { Makes strengths and achievements } \\
\text { known, talks about personal } \\
\text { success }\end{array}$ & Modest & $\begin{array}{l}\text { Dislikes discussing achievements, } \\
\text { keeps quiet about personal success }\end{array}$ \\
\hline $\begin{array}{l}\text { Prepared to make decisions without } \\
\text { consultation, prefers to make } \\
\text { decisions alone }\end{array}$ & Democratic & $\begin{array}{l}\text { Consults widely, involves others in } \\
\text { decision making, less likely to } \\
\text { make decisions alone }\end{array}$ \\
\hline $\begin{array}{l}\text { Selective with sympathy and } \\
\text { support, remains detached from } \\
\text { others' personal problems }\end{array}$ & Caring & $\begin{array}{l}\text { Sympathetic and considerate } \\
\text { towards others, helpful and } \\
\text { supportive, gets involved in others' } \\
\text { problems }\end{array}$ \\
\hline
\end{tabular}




\section{Appendix. Descriptions of the individual OPQ subscales from the OPQ technical manual (Bartram et al., 2006, p. 9-11) continued}

\begin{tabular}{|c|c|c|}
\hline $\begin{array}{l}\text { Behavior associated with low } \\
\text { scores }\end{array}$ & Subscales & $\begin{array}{l}\text { Behavior associated with high } \\
\text { scores }\end{array}$ \\
\hline \multicolumn{3}{|c|}{ Dimension 2: Thinking Styles } \\
\hline $\begin{array}{l}\text { Prefers dealing with opinions and } \\
\text { feelings rather than facts and } \\
\text { figures, likely to avoid using } \\
\text { statistics }\end{array}$ & Data Rational & $\begin{array}{l}\text { Likes working with numbers, } \\
\text { enjoys analysing statistical } \\
\text { information, bases decisions on } \\
\text { facts and figures }\end{array}$ \\
\hline $\begin{array}{l}\text { Does not focus on potential } \\
\text { limitations, dislikes critically } \\
\text { analysing information, rarely looks } \\
\text { for errors or mistakes }\end{array}$ & Evaluative & $\begin{array}{l}\text { Critically evaluates information, } \\
\text { looks for potential limitations, } \\
\text { focuses upon errors }\end{array}$ \\
\hline $\begin{array}{l}\text { Does not question the reasons for } \\
\text { people's behavior, tends not to } \\
\text { analyse people }\end{array}$ & Behavioral & $\begin{array}{l}\text { Tries to understand motives and } \\
\text { behaviors, enjoys analysing people }\end{array}$ \\
\hline $\begin{array}{l}\text { Favours changes to work methods, } \\
\text { prefers new approaches, less } \\
\text { conventional }\end{array}$ & Conventional & $\begin{array}{l}\text { Prefers well established methods, } \\
\text { favours a more conventional } \\
\text { approach }\end{array}$ \\
\hline $\begin{array}{l}\text { Prefers to deal with practical rather } \\
\text { than theoretical issues, dislikes } \\
\text { dealing with abstract concepts }\end{array}$ & Conceptual & $\begin{array}{l}\text { Interested in theories, enjoys } \\
\text { discussing abstract concepts }\end{array}$ \\
\hline $\begin{array}{l}\text { More likely to build on than } \\
\text { generate ideas, less inclined to be } \\
\text { creative and inventive }\end{array}$ & Innovative & $\begin{array}{l}\text { Generates new ideas, enjoys being } \\
\text { creative, thinks of original } \\
\text { solutions }\end{array}$ \\
\hline $\begin{array}{l}\text { Prefers routine, is prepared to do } \\
\text { repetitive work, does not seek } \\
\text { variety }\end{array}$ & $\begin{array}{l}\text { Variety } \\
\text { Seeking }\end{array}$ & $\begin{array}{l}\text { Prefers variety, tries out new } \\
\text { things, likes changes to regular } \\
\text { routine, can become bored by } \\
\text { repetitive work }\end{array}$ \\
\hline $\begin{array}{l}\text { Behaves consistently across } \\
\text { situations, unlikely to behave } \\
\text { differently with different people }\end{array}$ & Adaptable & $\begin{array}{l}\text { Changes behavior to suit the } \\
\text { situation, adapts approach to } \\
\text { different people }\end{array}$ \\
\hline $\begin{array}{l}\text { More likely to focus upon } \\
\text { immediate than long-term issues, } \\
\text { less likely to take a strategic } \\
\text { perspective }\end{array}$ & Forward Thinking & $\begin{array}{l}\text { Takes a long-term view, sets goals } \\
\text { for the future, more likely to take a } \\
\text { strategic perspective }\end{array}$ \\
\hline $\begin{array}{l}\text { Unlikely to become preoccupied } \\
\text { with detail, less organised and } \\
\text { systematic, dislikes tasks involving } \\
\text { detail }\end{array}$ & Detail Conscious & $\begin{array}{l}\text { Focuses on detail, likes to be } \\
\text { methodical, organised and } \\
\text { systematic, may become } \\
\text { preoccupied with detail }\end{array}$ \\
\hline $\begin{array}{l}\text { Sees deadlines as flexible, prepared } \\
\text { to leave some tasks unfinished }\end{array}$ & Conscientious & $\begin{array}{l}\text { Focuses on getting things finished, } \\
\text { persists until the job is done }\end{array}$ \\
\hline $\begin{array}{l}\text { Not restricted by rules and } \\
\text { procedures, prepared to break rules, } \\
\text { tends to dislike bureaucracy }\end{array}$ & Rule Following & $\begin{array}{l}\text { Follows rules and regulations, } \\
\text { prefers clear guidelines, finds it } \\
\text { difficult to break rules }\end{array}$ \\
\hline
\end{tabular}




\section{Appendix. Descriptions of the individual OPQ subscales from the OPQ technical manual (Bartram et al., 2006, p. 9-11) continued}

\begin{tabular}{llll}
\hline $\begin{array}{l}\text { Behavior associated with low } \\
\text { scores }\end{array}$ & & Subscales & $\begin{array}{l}\text { Behavior associated with high } \\
\text { scores }\end{array}$ \\
\hline
\end{tabular}

\section{Dimension 3: Feelings and emotions}

\begin{tabular}{|c|c|c|}
\hline $\begin{array}{l}\text { Tends to feel tense, finds it difficult } \\
\text { to relax, can find it hard to unwind } \\
\text { after work }\end{array}$ & Relaxed & $\begin{array}{l}\text { Finds it easy to relax, rarely feels } \\
\text { tense, generally calm and } \\
\text { untroubled }\end{array}$ \\
\hline $\begin{array}{l}\text { Feels calm before important } \\
\text { occasions, less affected by key } \\
\text { events, free from worry }\end{array}$ & Worrying & $\begin{array}{l}\text { Feels nervous before important } \\
\text { occasions, worries about things } \\
\text { going wrong }\end{array}$ \\
\hline $\begin{array}{l}\text { Sensitive, easily hurt by criticism, } \\
\text { upset by unfair comments or insults }\end{array}$ & Tough minded & $\begin{array}{l}\text { Not easily offended, can ignore } \\
\text { insults, may be insensitive to } \\
\text { personal criticism }\end{array}$ \\
\hline $\begin{array}{l}\text { Concerned about the future, } \\
\text { expects things to go wrong, focuses } \\
\text { on negative aspects of a situation }\end{array}$ & Optimistic & $\begin{array}{l}\text { Expects things will turn out well, } \\
\text { looks to the positive aspects of a } \\
\text { situation, has an optimistic view of } \\
\text { the future }\end{array}$ \\
\hline $\begin{array}{l}\text { Wary of others' intentions, finds it } \\
\text { difficult to trust others, unlikely to } \\
\text { be fooled by people }\end{array}$ & Trusting & $\begin{array}{l}\text { Trusts people, sees others as } \\
\text { reliable and honest, believes what } \\
\text { others say }\end{array}$ \\
\hline $\begin{array}{l}\text { Openly expresses feelings, finds it } \\
\text { difficult to conceal feelings, } \\
\text { displays emotion clearly }\end{array}$ & Emotionally Controlled & $\begin{array}{l}\text { Can conceal feelings from others, } \\
\text { rarely displays emotion }\end{array}$ \\
\hline $\begin{array}{l}\text { Likes to take things at a steady } \\
\text { pace, dislikes excessive work } \\
\text { demands }\end{array}$ & Vigorous & $\begin{array}{l}\text { Thrives on activity, likes to keep } \\
\text { busy, enjoys having a lot to do }\end{array}$ \\
\hline $\begin{array}{l}\text { Dislikes competing with others, } \\
\text { feels that taking part is more } \\
\text { important than winning }\end{array}$ & Competitive & $\begin{array}{l}\text { Has a need to win, enjoys } \\
\text { competitive activities, dislikes } \\
\text { losing }\end{array}$ \\
\hline $\begin{array}{l}\text { Sees career progression as less } \\
\text { important, looks for achievable } \\
\text { rather than highly ambitious targets }\end{array}$ & Achieving & $\begin{array}{l}\text { Ambitious and career-centred, likes } \\
\text { to work to demanding goals and } \\
\text { targets }\end{array}$ \\
\hline $\begin{array}{l}\text { Tends to be cautious when making } \\
\text { decisions, likes to take time to } \\
\text { reach conclusions }\end{array}$ & Decisive & $\begin{array}{l}\text { Makes fast decisions, reaches } \\
\text { conclusions quickly, less cautious }\end{array}$ \\
\hline
\end{tabular}

